UNIVERSIDADE DE SÃO PAULO

FACULDADE DE ECONOMIA, ADMINISTRAÇÃO E CONTABILIDADE DEPARTAMENTO DE CONTABILIDADE E ATUÁRIA

PROGRAMA DE PÓS-GRADUAÇÃO EM CONTROLADORIA E CONTABILIDADE

Desvendando a opinião da auditoria independente:

o resultado da auditoria

Rudah Giasson Luccas

Orientador: Prof. Dr. Gerlando Augusto Sampaio Franco de Lima

SÃO PAULO

2015 
Prof. Dr. Marco Antônio Zago

Reitor da Universidade de São Paulo

Prof. Dr. Adalberto Américo Fischmann

Diretor da Faculdade de Economia, Administração e Contabilidade

Prof. Dr. Gerlando Augusto Sampaio Franco de Lima

Chefe do Departamento de Contabilidade e Atuária

Prof. Dr. Ândson Braga de Aguiar

Coordenador do Programa de Pós-Graduação em Controladoria e Contabilidade 
RUDAH GIASSON LUCCAS

\title{
DESVENDANDO A OPINIÃO DA AUDITORIA INDEPENDENTE: O RESULTADO DA AUDITORIA
}

Dissertação a apresentar ao Departamento de Contabilidade e Atuária, da Faculdade de Economia, Administração e Contabilidade, da Universidade de São Paulo, como requisito para obtenção do título de Mestre em Ciências.

Área de concentração: Auditoria

Orientador: Prof. Dr. Gerlando Augusto Sampaio Franco de Lima

\author{
SÃO PAULO
}


Autorizo a reprodução e divulgação total ou parcial deste trabalho, por qualquer meio convencional ou eletrônico, para fins de estudo e pesquisa, desde que citada a fonte.

\section{FICHA CATALOGRÁFICA}

Elaborada pela Seção de Processamento Técnico do SBD/FEA/USP

Luccas, Rudah Giasson

Desvendando a opinião da auditoria independente: o resultado da auditoria / Rudah Giasson Luccas. -- São Paulo, 2015.

$75 \mathrm{p}$.

Dissertação (Mestrado) - Universidade de São Paulo, 2015.

Orientador: Gerlando Augusto Sampaio Franco de Lima.

1. Auditoria 2. Teoria de auditoria 3. Relatório de auditoria 4. Qualidade de auditoria 5. Clusters I. Universidade de São Paulo. Faculdade de Economia, Administração e Contabilidade. II. Título.

CDD - 657.45 


\section{RESUMO}

A presente pesquisa objetiva analisar as teorias acerca do processo de auditoria e sua relação com a opinião expressa no relatório de auditoria. A associação estudada se diferencia de outros estudos no arcabouço teórico de auditoria, tanto no cenário nacional, quanto no cenário internacional, ao detectar a opinião esperada frente à qualidade da contabilidade da empresa e à qualidade vinculada à firma de auditoria, em métricas ex ante ao relatório da auditoria. $\mathrm{O}$ arcabouço teórico, base para esta pesquisa, é a teoria dos custos contratuais. O estudo detectou e explorou nos principais periódicos internacionais fatores determinantes a qualidade da auditoria ex ante, sendo detectado: (I) a reputação/competência do auditor, (II) a especialização do auditor, (III) o atraso na emissão do relatório de auditoria e (IV) o tamanho da firma de auditoria. O método estatístico identificado para averiguação e detecção do objetivo da pesquisa é a regressão logística binária. Procurando identificar anomalias do modelo, as técnicas de análise de clusters e análise multidimensional foram utilizadas para identificar possíveis relações entre os setores. As análises exploratórias demonstraram a separação dos setores em três clusters categorizados pelo acerto do modelo e, após, foram identificadas semelhanças dentre os setores nos grupos formados. O primeiro, dentre os clusters, possui mais setores e comportamento equivalente ao conjunto de empresas abertas brasileiras. Outro cluster, contendo companhias nos setores de Agro e Pesca, Química, Energia Elétrica, Mineração, Minerais não Metalúrgicos e Petróleo e Gás, possui particularidades à opinião do auditor independente, no comparativo à amostra. Neste grupo da amostra o modelo proposto não possui assertividade aos pareceres com modificação de opinião. O terceiro conjunto de setores é composto de empresas com alta quantidade de pareceres sem modificação de opinião, não havendo correlação à amostra estudada. A relação entre a qualidade da auditoria ex ante e a opinião do auditor independente também foi testada, a fim de se detectar os principais motivos de anomalia no modelo e a separação da amostra em subgrupos. Como resultado, identificou-se uma associação atemporal entre a opinião da auditoria e as métricas de qualidade da contabilidade e de qualidade da auditoria para as empresas abertas do Brasil.

Palavras-chave: Auditoria. Teoria de auditoria. Relatório de auditoria. Qualidade da auditoria. Cluster. 



\section{AbStract \\ Uncovering the opinion of independent auditors: The result of the audit}

The present research aims to analyze the theories of the audit process and its relation to the expressed opinion in the audit report. The studied association differs from other audit theoretical frameworks, both on the national and international scenarios, as detects the expected audit opinion against the quality of the entity accounting and the quality linked to the audit firm, in metrics ex ante to the audit report. The basis for this research is the theory of contract costs. The study discovered and explored in major international models determinants the quality of ex ante audit, being detected: (I) the reputation / auditor competence, (II) the specialization of the auditor, (III) the delay in the issuance of the audit report and (IV) the size of the audit firm. The statistical method identified for investigation and detection of the goal in the research is the binary logistic regression. Seeking to identify anomalies in the proposed model, the techniques of multidimensional analysis and cluster analysis were used to identify possible relationships between sectors. Exploratory analyzes showed the separation of sectors into three clusters categorized by accuracy of the proposed model and, after that, similarities were identified among the sectors in the formed groups. The first, between the clusters, has more sectors and has equivalent behavior to the group of Brazilian public-listed companies. Another cluster, including companies from different industries like Agro, Fishing, Chemical, Energy, Minerals not Metallurgical and oil and gas, hold particularities in the external audit opinion, in comparison to the sample. On this the group the proposed model does not hold assertiveness regarding reports with modified opinions. The third set of sectors comprises companies in which the audit reports without modified opinions, and has no correlation to the others. The relationship between ex ante audit quality and the auditor opinion was also tested, in order to detect the model unconformity and the segregation of the sample into subgroups. As a result, it was identified that there is association between the auditors' opinion and the accounting quality metrics and quality regarding the public-listed companies in Brazil.

Keywords: Audit. Audit theory. Audit report. Audit quality. Cluster. 



\section{SUMÁRIO}

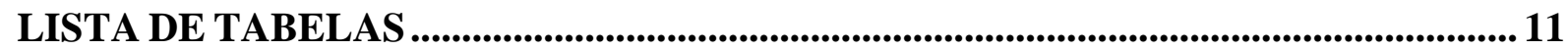

LISTA DE FIGURAS........................................................................................................ 12

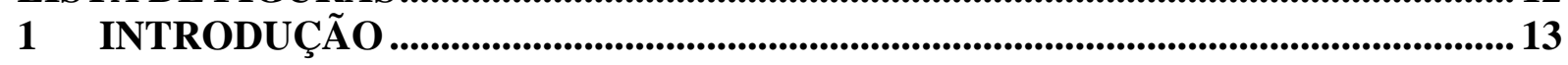

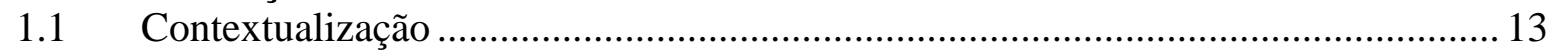

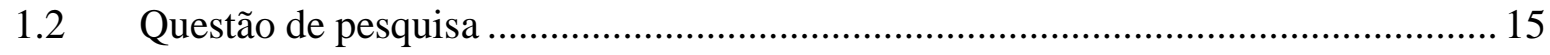

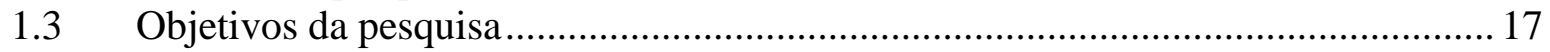

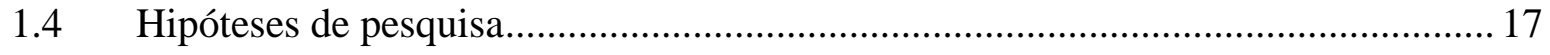

1.5 Originalidade e contribuições............................................................................. 18

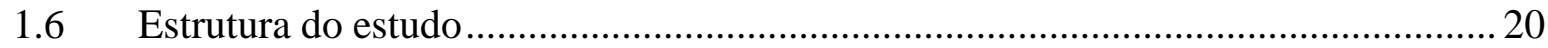

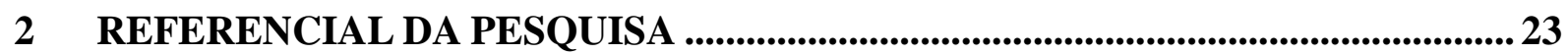

$2.1 \quad$ A previsibilidade do relatório de auditoria.......................................................... 23

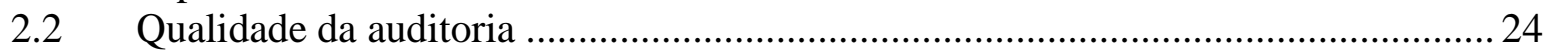

2.2.1 Reputação/competência - quase-renda ............................................................ 24

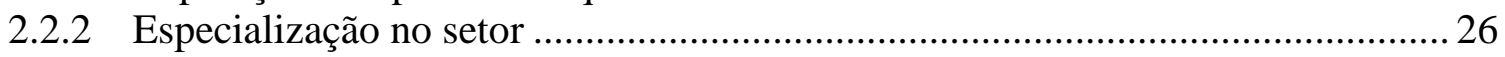

2.2.3 Audit delay ……………………………………………………………... 27

2.2.4 Tamanho da auditoria .................................................................................. 28

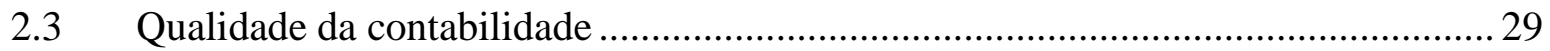

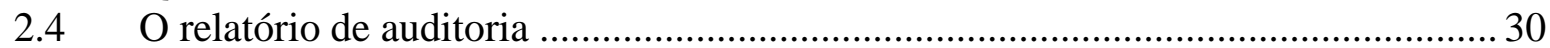

2.5 Teorias da qualidade da auditoria e da contabilidade …………………………..... 32

3 DESENHO DA PESQUISA .......................................................................................33

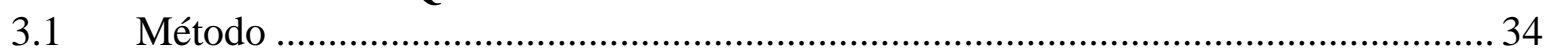

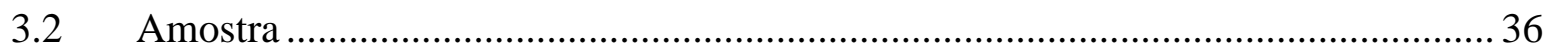

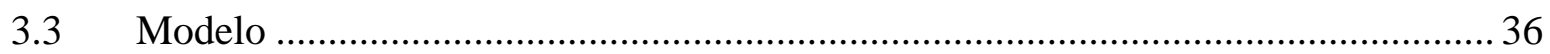

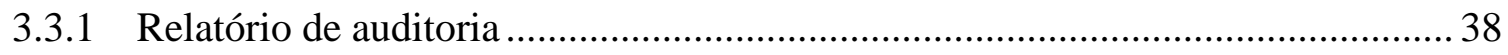

3.3.2 Qualidade da contabilidade ......................................................................... 39

3.3.3 Qualidade da auditoria ............................................................................. 40

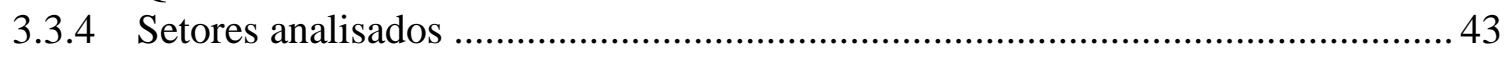

4 RESULTADOS............................................................................................................... 45

4.1 Análise dos resultados do modelo global ................................................................ 45

4.2 Resultados do modelo de previsibilidade do parecer de auditoria ............................. 46

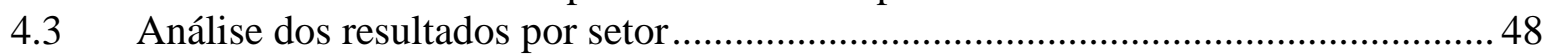

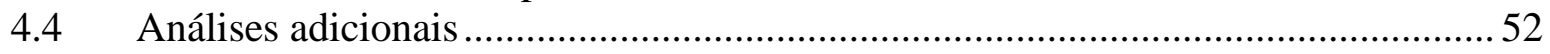

4.4.1 Análise dos resultados temporais ..................................................................... 52

4.4.2 Análise descritiva por cluster ............................................................................5 54

4.4.3 Análise dos resultados e a qualidade da auditoria ................................................5

5 CONSIDERAÇÕES ........................................................................................63

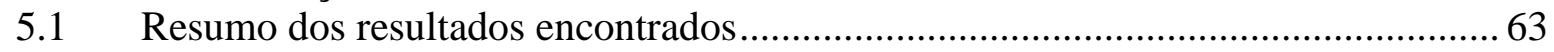

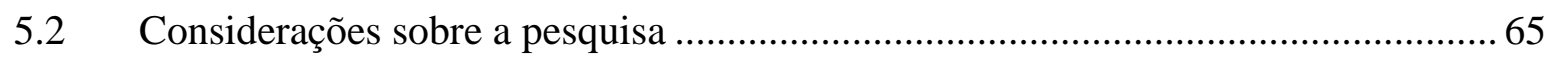

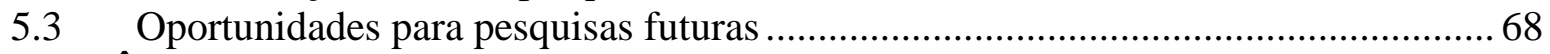

REFERÊNCIAS .........................................................................................................69 



\section{LISTA DE TABELAS}

Tabela 1 - Resumo teorias da qualidade da auditoria e da contabilidade .............................. 32

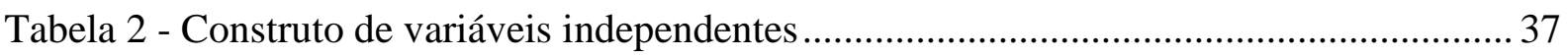

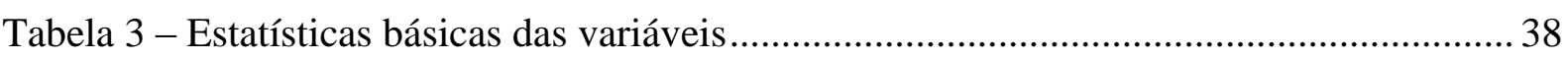

Tabela 4 - Firma de auditoria e empresas de grande porte .................................................. 43

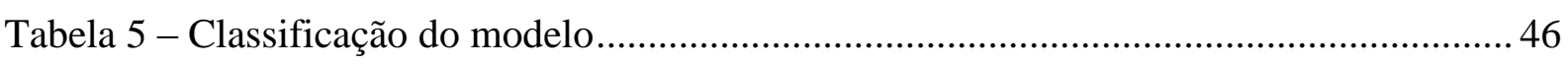

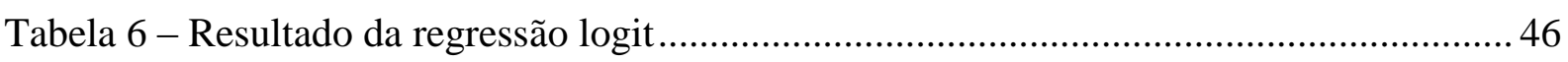

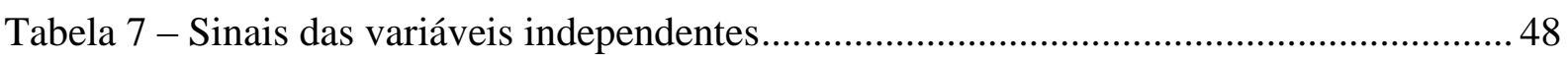

Tabela 8 - Análise exploratória do modelo global por setor .................................................. 51

Tabela 9 - Correlação temporal da curva de probabilidade do parecer de auditoria -

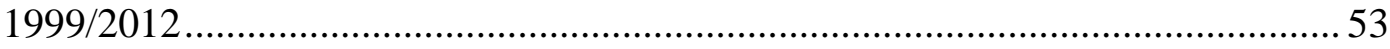

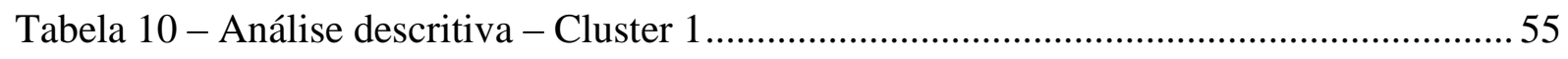

Tabela 11 - Probabilidade (\%) do Audit Outcome e a qualidade da auditoria ........................58

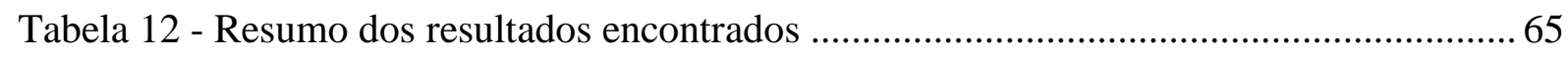

Tabela 13 - Resumo dos impactos dos fatores na opinião do auditor ..................................... 66 


\section{LISTA DE FIGURAS}

Figura 1 - Publicações sobre auditoria nos principais periódicos internacionais - 1981/201320

Figura 2 - Estrutura da validade preditiva - parecer de auditoria ......................................... 34

Figura 3 - Evolução do parecer de auditoria - 1999/2012 …............................................... 39

Figura 4 - Comportamento de variáveis da qualidade da contabilidade................................ 40

Figura 5 - Comportamento da variável quase-renda .......................................................... 41

Figura 6 - Comportamento variáveis especialização no setor ................................................ 42

Figura 7 - Curva de probabilidade do parecer de auditoria ................................................. 45

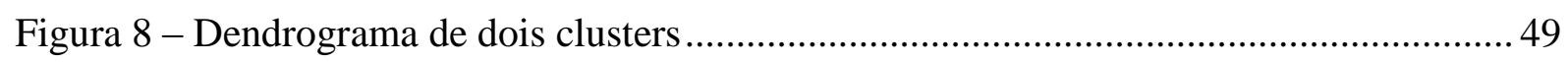

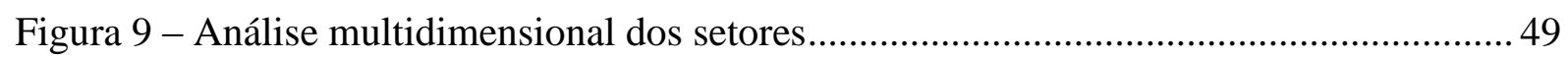

Figura 10 - Curva de probabilidade do parecer de auditoria - Cluster 1 ................................ 54

Figura 11 - Curva de probabilidade do parecer de auditoria - Cluster 2 ...............................56

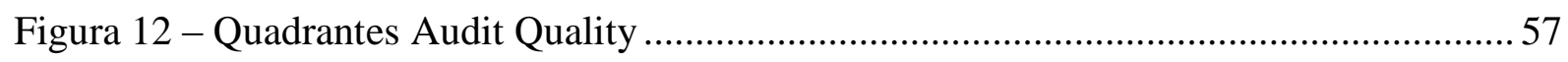

Figura 13 - Curva de probabilidade do parecer e a qualidade da auditoria - opinião limpa ... 59

Figura 14 - Curva de probabilidade do parecer e a qualidade da auditoria - opinião

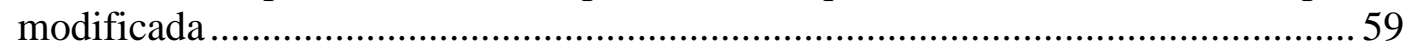

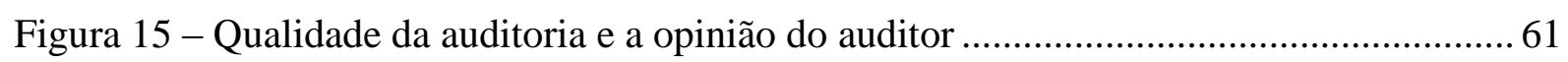




\title{
1 INTRODUÇÃOO
}

\author{
Diz-me como me medes, \\ e eu te direi como me comporto \\ (autor anônimo)
}

\subsection{Contextualização}

Os auditores independentes atuam, fundamentalmente, como intermediários informacionais de gestores e stockholders ${ }^{1}$, e seus relatórios objetivam incrementar a confiabilidade (e, por conseguinte, a qualidade) das demonstrações contábeis, particularmente junto àqueles stakeholders $^{2}$ que não possuem a mesma facilidade de acesso à informação que possuem os gestores. A atuação dos auditores constitui, portanto, em um mecanismo de quebra de assimetria de informação, através da governança corporativa, já que sua atuação procura reduzir o problema de conflitos entre insiders e outsiders (Sunder, 1997; Arruñada, 1997).

A inserção do auditor na relação entre acionista (outsider) e gestor (insider), no entanto, não apenas altera a relação informacional entre estes. Esse novo atuante dá origem a duas novas relações - auditor - gestor e acionista - agestor -, gerando assim novo custo de agência, associado a esse agente que não existia anteriormente (Sunder, 1997). Assim, a resultante do contrato conjunto desses três agentes deve trazer melhores perspectivas para cada um deles, comparadas ao que eles poderiam obter sozinhos ou formando coalizões menores. Quando o custo marginal de reduzir o risco de auditoria é igual ao benefício marginal através de todos os instrumentos de redução de risco no arsenal dos auditores, encontra-se o ponto de equilíbrio na relação e, por fim, a mitigação de conflitos entre insiders e outsiders.

\footnotetext{
${ }^{1}$ Stockholder (sócio): agente que legalmente possui participação, ou ação, em uma companhia privada ou pública.

${ }^{2}$ Stakeholders (agentes): um grupo de interesse ou sistema que afeta ou é afetado pelas ações de uma companhia.
} 
A fim de reduzir a assimetria informacional, o auditor emite uma opinião sobre as demonstrações financeiras da companhia. Essa opinião é pautada sobre quesitos de prática contábil, de escopo do trabalho de auditoria e de incerteza acerca da saúde financeira da empresa auditada. O usuário externo, comumente investidor, através das demonstrações financeiras avalia a capacidade da companhia de gerar fluxos de caixa futuros, para, então, tomar a decisão de compra, venda ou manutenção de investimento. Segundo Sunder (1997), nesse ambiente, a opinião do auditor é de suma importância para redução do custo de capital. Nesse contexto, os acionistas poderão demandar uma taxa inferior de retorno sobre seu patrimônio, devido à confiança acerca das demonstrações financeiras da entidade analisada.

O trabalho do auditor, no entanto, não se resume a avaliar a companhia e emitir um relatório. Para fins de órgãos reguladores, o auditor tem como dever e responsabilidade a análise do compliance das demonstrações financeiras de uma companhia às normas contábeis, verificando se a companhia divulga obrigações acessórias obrigatórias, se realiza as destinações do resultado de acordo com as disposições à qual está regulada e se a companhia auditada possui eventual descumprimento das disposições legais e regulamentares aplicáveis. Além disto, o auditor deverá elaborar relatório circunstanciado acerca das deficiências ou ineficiências no controle interno e dos procedimentos contábeis da companhia auditada, enviando-o à administração e ao Conselho Fiscal (se solicitado). Outros trabalhos do auditor compreendem: conservação de papéis de trabalho; acesso aos órgãos reguladores das informações analisadas e possibilitar acesso do novo auditor em caso se substituição.

O processo de auditoria tem início na escolha da firma para auditar um determinado cliente. Para as empresas, o processo tem início quando estas trocam seus auditores externos ou os contratam pela primeira vez, após receber ofertas de diversas firmas de auditoria.

Na licitação para um novo compromisso, os auditores avaliam potenciais receitas ao longo de vários anos (pois as grandes empresas abertas não alteram os auditores frequentemente ${ }^{3}$ ).

\footnotetext{
${ }^{3}$ No Brasil, através da Instrução 308 da CVM de 1999, foi instaurada a rotação obrigatória dos auditores independentes ("rodízio"). De acordo com o artigo 31 da instrução, o auditor independente não pode prestar serviços para um mesmo cliente, por prazo superior a cinco anos consecutivos. Dentre as companhias abertas no Brasil nota-se uma relação de anos consecutivos entre firma e companhia entre 2 e 3 anos (Braunbeck, 2010).
} 
Assim como as firmas de auditoria possuem a oportunidade de construir reputação, seus clientes, também beneficiam-se da mesma oportunidade.

Uma empresa paga uma taxa extra de auditoria para se associar a reputação de um bom auditor, e uma empresa de auditoria aceitará uma taxa inferior de uma empresa que possui uma reputação com integridade e boa gestão financeira. Clientes com boa gestão impõem menos risco sobre o auditor, que poderá emitir um parecer após menos tempo de exame. Enquanto isso, os clientes com má gestão contábil impõem risco legal, financeiro e de imagem ao auditor.

A firma de auditoria, portanto, considerará, na seleção da empresa a ser auditada, sua qualidade financeira. Caso a companhia não possua alta qualidade contábil, as taxas exigidas pelo auditor serão superiores, pois a firma de auditoria deverá se resguardar de possíveis riscos agregados ao cliente (DeAngelo, 1981a; Hribar, Kravet, \& Wilson, 2010).

Os auditores, porém, podem mitigar o risco de seus trabalhos através do aumento dos intangíveis. Uma alta qualidade da auditoria, tanto técnica quanto reputacional, afetará o custo do serviço do auditor. A firma que possui alta especialização em um segmento, por exemplo, poderá detectar falhas que outras firmas não detectariam, e com custo inicial inferior ao da firma não especializada (Simunic \& Stein, 1987).

Vis-à-vis o processo de escolha de uma firma a ser auditada e a emissão do relatório final, nota-se a importância de detectar os fatores que influenciam a opinião do auditor. Assim sendo, a problemática na qual se insere o presente estudo se ampara na escolha do auditor independente para auditar determinada companhia, comumente expressa na literatura internacional como qualidade da auditoria ex ante. Nesse contexto, procura-se detectar se há a possibilidade de relacionar os motivos para tal escolha com a opinião do auditor no relatório de auditoria emitido.

\subsection{Questão de pesquisa}

DeAngelo (1981a) e Watts e Zimmerman (1986) definem a qualidade da auditoria como a probabilidade conjunta de um auditor vir a detectar uma falha no sistema contábil de seu 
cliente e de que a informe por meio do seu parecer. Utilizando a abordagem dos citados autores, Arruñada (1997) complementa a análise de probabilidade como uma razão entre competência técnica e independência do auditor. Independência, para o autor, é a posição do auditor ao fazer refletir nos relatórios de auditoria todos os defeitos e problemas que detectou no processo de revisão dos dados contábeis. Enquanto isso, o autor define como competência técnica a capacidade do auditor para detectar defeitos ou erros nos demonstrativos financeiros que verifica, ou seja, a probabilidade de uma firma detectar defeitos nos dados contábeis de uma companhia auditada.

Entretanto, vale destacar pesquisas que distinguem a qualidade da auditoria pré-contratação e a da auditoria pós-contratação do auditor independente. Simunic e Stein (1987) definem a qualidade da auditoria ex ante (no momento da contratação do serviço de auditoria) como a probabilidade de detecção material dos erros no relatório financeiro. Os pesquisadores, portanto, exploram os fatores que influenciam a independência e a competência do auditor independente pré-contratação, e.g., como a capacidade técnica e os procedimentos de auditoria.

Keefe, King e Gaver (1994) relatam que os usuários das demonstrações financeiras se preocupam com os efeitos da qualidade da auditoria na fase ex post $^{4}$, pois a opinião do auditor ajuda a medir a qualidade da demonstração. Essa qualidade da auditoria após o parecer, e contratação, está relacionada principalmente a republicação das demonstrações financeiras, troca de auditores e mudanças na opinião do auditor independente, comparadas ao período anterior ou ao período subsequente.

Entretanto, as pesquisas não definem a relação da qualidade da auditoria ex ante e ex post com a opinião do auditor independente.

A qualidade financeira de uma companhia constitui fator primordial para a qualidade da auditoria, como detectado anteriormente. As decisões (triggers) da auditoria se relacionam com a mitigação de riscos presentes e futuros com seu portfólio de clientes. Nesse contexto, a

\footnotetext{
4 A qualidade da auditoria ex post (no momento em que a demonstração financeira é divulgada) é a probabilidade de a demonstração financeira não possuir erros materiais.
} 
qualidade da contabilidade procura identificar o comportamento dos gestores em relação à tratativa de eventos econômicos.

De acordo com Martins e Theóphilo (2009), um problema de pesquisa se origina da inquietação, da dúvida, da hesitação, da perplexidade, da curiosidade sobre uma questão não resolvida. Nessa perspectiva, parece razoável pesquisar:

Qual a associação da opinião contida no relatório de auditoria com as métricas de qualidade da auditoria ex ante e de qualidade da contabilidade?

\subsection{Objetivos da pesquisa}

A estruturação de um objeto de estudo valer-se-á do pesquisador a fim de distinguir as ações que esse estudo adotará. Dessa forma, é razoável aferir que o objetivo geral desta pesquisa consiste em avaliar um modelo de estimação da opinião do auditor independente à luz das teorias de qualidade da auditoria e de qualidade da contabilidade. Almejando identificar se a opinião do auditor, dada a sua predisposição inicial para o relacionamento, é previsível.

A fim de auxiliar na construção e no atendimento da questão de pesquisa e do objetivo supramencionado, o estudo tem os seguintes objetivos específicos:

I. identificar as teorias de alicerce do processo de auditoria;

II. explorar as particularidades dos setores na associação entre o relatório de auditoria e as métricas de qualidade da auditoria e de qualidade da contabilidade; e

III. identificar desvios entre a qualidade da auditoria, a opinião do auditor e a probabilidade de o parecer possuir uma opinião específica (segundo o modelo proposto).

\subsection{Hipóteses de pesquisa}

Martins e Theóphilo (2009) sugerem que hipóteses são proposições afirmativas que pretendem responder preliminarmente à questão de pesquisa. 
Portanto $^{5}$, são apresentadas, a seguir, as hipóteses a serem testadas neste estudo:

Hipótese 1: Há associação entre a opinião do auditor contida no relatório de auditoria e as métricas de qualidade da contabilidade.

Hipótese 2: Há associação entre a opinião do auditor contida no relatório de auditoria e as métricas de qualidade da auditoria.

A fim de atender às motivações e às questões desta pesquisa, a associação tratada nas hipóteses de pesquisa objetiva captar efeitos ex ante e durante o processo de auditoria de uma companhia ${ }^{6}$.

\subsection{Originalidade e contribuições}

Esta pesquisa visa contribuir e enriquecer o cenário nacional e internacional de pesquisas em auditoria, buscando uma visão alternativa e obtendo resultados relevantes em consonância ao objetivo da pesquisa. A associação proposta no objetivo deste estudo encontra cenário favorável no Brasil, devido à pequena quantidade de pareceres sem modificação $\left(58,8 \%{ }^{7}\right)$, sendo que as conclusões acerca do mercado brasileiro são úteis ao mercado e à academia. As influências dos resultados empíricos e o arcabouço teórico podem servir ao mercado na análise das empresas (caso exista uma empresa com um parecer sem modificação de opinião, enquanto há uma baixa qualidade da contabilidade e baixa qualidade da auditoria, há indícios de que no processo de auditoria o auditor cedeu às suas quase-rendas - incerteza associada a altos payoffs contratuais). As descobertas agregam conhecimento acadêmico na exploração das diferenças entre os setores e a detecção de desdobramento dos motivos das diferenças encontradas.

À academia, as principais contribuições desta pesquisa são: (I) referencial teórico embasado nos principais periódicos internacionais; (II) construção do modelo de estimação do parecer de auditoria, junto à variáveis de auditoria pré a emissão do relatório de auditoria; e (III)

\footnotetext{
${ }^{5}$ De acordo com a primeira etapa da estrutura da validade preditiva do parecer de auditoria, exposta no desenho da pesquisa (libby box).

${ }^{6}$ Assim sendo, a etapa 2 do libby box considerou esse recorte no arcabouço teórico para o construto das variáveis independentes.

${ }^{7}$ Dados do estudo, contidos na seção 3.2.
} 
utilização de variáveis de quase-renda e especialização alternativas, analisando perspectivas de market-share, assim podendo contribuir à modelos de qualidade da auditoria. A ampla base de dados da pesquisa, agregando informações financeiras e de auditores das empresas abertas brasileiras desde 1998, contribuirá à academia através da ampliação (novas variáveis independentes ou novos dados) do horizonte pesquisado, por este ou outros pesquisadores.

Ao mercado e a sociedade, a pesquisa contribuirá ao atestar a relação entre auditor e companhia auditada. No Brasil, nenhuma pesquisa anterior foi identificada tratando e explorando as relações prévias entre opinião do auditor independente e características da companhia auditada. Nota-se nos últimos anos uma evolução acerca dos mercados de capitais no Brasil, assim demandando melhores práticas de governança das companhias. A relação do auditor-auditado deverá agregar valor à companhia e aos membros da sociedade interdependentes. Assim, deverão ser identificadas ineficiências econômicas na relação auditor-administração e mitigação para fins de benefícios à sociedade. Braunbeck (2010) constata a importância da pesquisa em auditoria junto ao mercado de capitais através da revisão da quantidade de publicações nos principais periódicos internacionais, e constatação do cenário da pesquisa. Para a constituição do referencial teórico, e afirmação acerca da originalidade da presente pesquisa, julgou-se necessário realizar uma revisão preliminar e a identificação das principais fontes bibliográficas.

A base de dados elaborada pela Thomson Reuters, Social Sciences Citation Index (SSCI), contém os principais periódicos internacionais na área da contabilidade ${ }^{8}$, sendo esses os que possuem o maior fator de impacto ${ }^{9}$. Na última década, mais de 800 artigos foram publicados nos principais periódicos internacionais sobre auditoria. Os artigos analisados datam dos

\footnotetext{
${ }^{8}$ Em 2010, os principais periódicos são: Auditing: A Journal of Practice \& Theory, Accounting Review, Contemporary Accounting Research, Accounting Horizons, European Accounting Review, Journal of Accounting Research, Accounting \& Business Research, Accounting \& Finance, Abacus, Journal of Business Finance \& Accounting, Journal of International Financial Management \& Accounting e Journal of Management Accounting Research.

${ }^{9}$ Reflete o número médio de citações de artigos científicos publicados em determinado periódico.
} 
últimos 15 anos (com exceção do periódico Auditing: A Journal of Practice \& Theory, que foi considerado desde sua criação ${ }^{10}$ ).

Figura 1 - Publicações sobre auditoria nos principais periódicos internacionais $1981 / 2013$

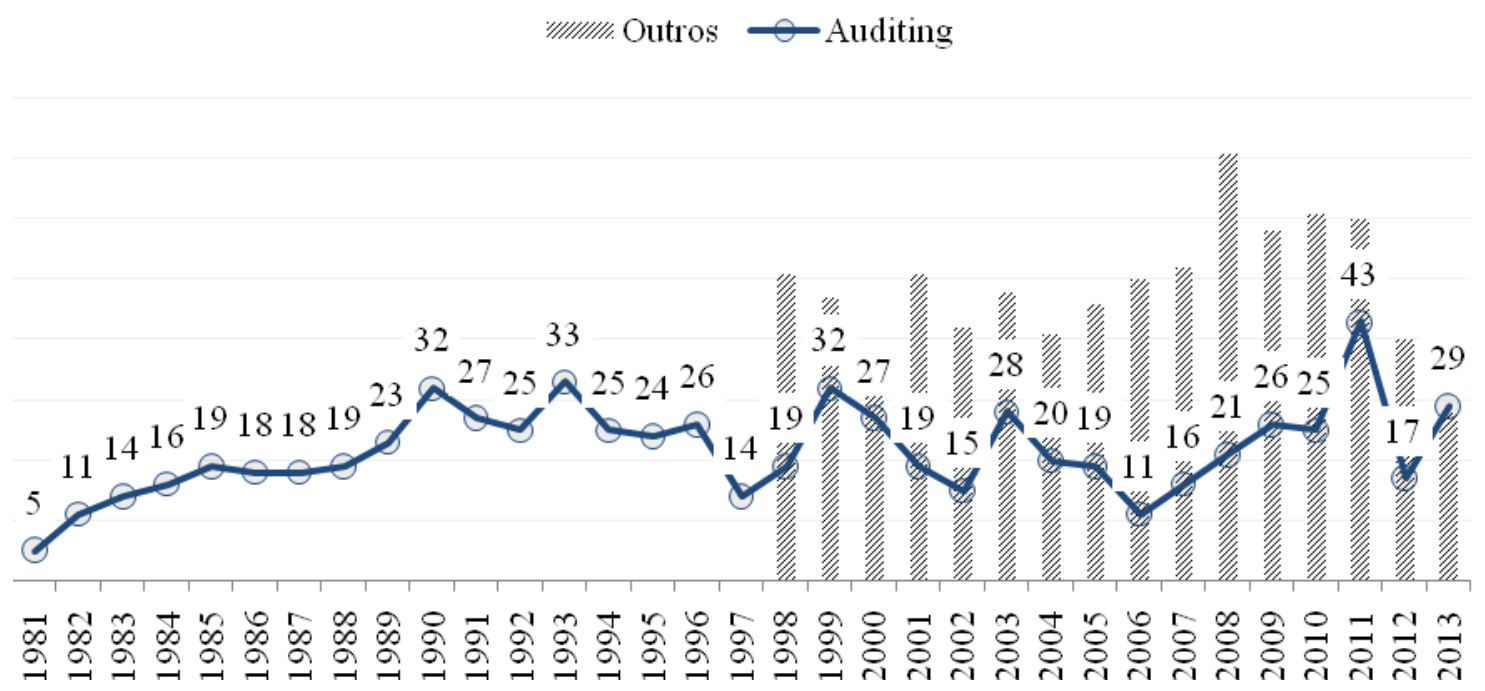

\subsection{Estrutura do estudo}

A fim de atingir o objetivo da pesquisa, este trabalho está estruturado da seguinte forma:

1. a primeira seção discute o ambiente, a situação, a hipótese, junto à originalidade e às contribuições desta pesquisa, conceitos que servirão de base na estruturação do estudo;

2. a segunda seção apresenta o embasamento teórico, junto aos conceitos que servirão como pilares desta pesquisa;

3. o capítulo 3 apresenta o desenho da pesquisa, as variáveis a serem estudadas, de acordo com o referencial teórico da seção anterior, e, por fim, a amostra de empresas analisadas;

4. o quarto capítulo apresenta os resultados encontrados, o que envolve atingir os objetivos propostos e responder à questão de pesquisa;

\footnotetext{
${ }^{10}$ Auditing: A Journal of Practice \& Theory foi analisado desde sua origem, devido à especificidade no tema auditoria.
} 
5. a última seção oferece as considerações desta pesquisa, dentre as quais encontra-se um resumo dos resultados encontrados e as conclusões, junto a limitações e indicações para futuras pesquisas. 


\section{REFERENCIAL DA PESQUISA}

\subsection{A previsibilidade do relatório de auditoria}

O processo de auditoria funciona como uma das maneiras de enforcement e de controle sobre a contabilidade. Watts e Zimmerman (1983) ressaltam a evolução conjunta da contabilidade e da auditoria na história das corporações. Segundo eles, essa evolução pode ser explicada pela Teoria dos Contratos. Os alicerces sobre os quais surge a teoria da auditoria são: a Teoria da Agência, a assimetria informacional e os processos políticos (custos contratuais).

Segundo Jensen e Meckling (1976), a firma é uma "caixa preta" que busca a maximização de seu valor presente. Assim, a Teoria da Agência apoia-se fundamentalmente na premissa de que (1) os indivíduos comportam-se no sentido de maximizar sua função-utilidade; (2) as firmas são organizações que abrangem distintos e diversos interesses, que assumem custos e recebem benefícios conforme especificações contratuais, sejam elas implícitas ou explícitas; (3) o comportamento dos indivíduos nas organizações dependerá fundamentalmente da natureza dos contratos; (4) em cada contrato, há um sujeito ativo (denominado "principal”), que demanda do sujeito passivo (denominado "agente") um determinado "produto" (sentido amplo), e, para tanto, o principal delega poderes e direitos aos agentes, que, na persecução do "produto" demandado, percebem algum tipo de benefício ou contraprestação pela ação executada (Braunbeck, 2010).

Já a assimetria informacional se relaciona com a ideia de descrição de um fenômeno segundo o qual alguns agentes econômicos dispõem de mais informações do que outros. Assim, quando existe assimetria informacional, há uma tendência maior de ocorrência de conflitos de interesse, devido à dificuldade de se distinguir entre o bom e o mau negócio (Akerlof, 1970).

A Teoria dos Custos Contratuais demonstra as preocupações das firmas de auditoria em relação a: reputação, reputação da classe, organização em relação a tamanho e especialização em determinados setores (Watts \& Zimmerman, 1986). Compreende-se, dessa forma, que os 
auditores independentes atuam como intermediários informacionais, no contexto de firmas (como nexo contratual) em condições de assimetria informacional e conflito de agência, o que corrobora a premissa de que a prática contábil da auditoria é explicada à luz do conflito de agência. Espera-se que esse intermediário entre o principal e o agente seja suficientemente competente e independente (Sunder, 1997; Lopes et al, 2012).

Da Teoria dos Contratos, atrelada aos processos políticos, segundo Watts e Zimmerman (1986), derivam fatores que demonstram as salvaguardas para assegurar o processo da auditoria. Os fatores a abordar na pesquisa que representam a qualidade da auditoria e as escolhas da auditoria em aceitar, ou não, um determinado cliente (audit choice) são: (I) reputação/competência, (II) especialização, (III) audit delay e (IV) tamanho da auditoria. Esses fatores são detalhados em seção específica (2.2), e procuram diferenciar os conflitos entre sócio, auditor e gestor, em função das dimensões ou atributos da qualidade da auditoria, isto é, da competência técnica e da independência.

Os fatores determinantes da qualidade da contabilidade foram discutidos por Barth, Landsman e Lang (2008) e Chen, Quingliang, Jiang e Lin (2010). Os métodos operacionais que objetivam captar os efeitos teóricos são (I) gerenciamento de resultado seguindo a meta e (II) reconhecimento tempestivo de perdas. Assim sendo, este estudo analisou a qualidade da contabilidade como sendo fator determinante na estimação de um parecer de auditoria. Essas variáveis são detalhadas no arcabouço teórico de qualidade da contabilidade, apresentado em seção específica (2.3).

\subsection{Qualidade da auditoria}

\subsubsection{Reputação/competência - quase-renda}

A escolha ex ante do auditor para auditar a empresa depende de sua habilidade para descobrir quebra ou erro no sistema contábil e, depois, feita a descoberta, do seu poder para não ceder à pressão do cliente. A quase-renda relacionada a um cliente específico, segundo DeAngelo (1981a) e Braunbeck (2010), surge na comparação entre as receitas provindas e os custos evitáveis.

Para o aceite, portanto, o valor presente dos investimentos iniciais e das receitas futuras deve exceder os futuros custos em ordem de que o cliente seja aceito. Esses custos podem ser 
considerados evitáveis e não evitáveis. Sendo que estes últimos surgem de problemas legais, por exemplo.

Caso não haja quase-renda de um cliente específico, o auditor é indiferente ao término da relação, e, consequentemente, não possui incentivos econômicos para esconder quaisquer descobertas (DeAngelo, 1981a).

Braunbeck (2010) utiliza como métrica para a mensuração das quase-rendas a detecção das seguintes questões:

- o auditor emitiu um parecer mais "rigoroso" em seu último ano antes de ser substituído?; e

- o parecer emitido pela empresa sucessora em um dos seus dois primeiros anos de auditoria teve uma abordagem menos "rigorosa" que a do último parecer emitido pelo auditor sucedido?

As questões abordadas por Braunbeck fazem parte da formação de um indicador de qualidade da auditoria (IQUA), baseado na conceituação teórica de Arruñada (1997) e contextualizado ao mercado brasileiro. Porém, essas questões não poderão ser utilizadas para estudo, por analisarem o evento após sua ocorrência, o que o torna inviável para o objetivo de analisar a estimação que o presente estudo se propõe. Dessa forma, serão analisados os indicadores de quase-renda ex ante ao relatório do auditor.

A falta de divulgação para empresas brasileiras sobre os honorários de auditoria se evidencia como fator que dificulta aferir as quase-rendas. A exigência da Comissão de Valores Mobiliários (CVM) data de 2010, com a demanda, para as companhias, de descrição sobre os gastos com auditoria no grupo 2 do formulário de referência. Outro fator de quase-renda é a existência de litígios para a firma de auditoria, devido à não detecção de fraudes nas demonstrações financeiras de uma companhia, gerando custos financeiros e legais para a firma (Mong \& Roebuck, 2005). Entretanto, esses valores não são identificáveis no momento da emissão de um parecer. 
Portanto, a fim de se capturar os efeitos de quase-renda na relação auditor e cliente, detectouse como variável a concentração dos ativos de uma companhia sobre o total de ativos no portfólio da firma de auditoria. Esse construto procura identificar a independência na decisão do auditor, ao informar, ou não, uma anomalia detectada nas demonstrações financeiras de um cliente (Arruñada, 1997). Não foram detectadas outras variáveis que pudessem detectar o fenômeno quase-renda, em pesquisas tanto nacionais, quanto internacionais.

\subsubsection{Especialização no setor}

A especialização na indústria pode ser vista como o uso de diferentes estratégias com o propósito de criar vantagem competitiva em relação a auditores não especialistas (Casterella, Francis, Lewis, \& Walker, 2004). Assim sendo, pode ser considerada a extensão da quaserenda, procurando mitigar possíveis custos. A diferenciação terá impacto (1) na taxa de auditoria (fee) (Casterella et al., 2004; Huang, Liu, Raghunandan, \& Rama, 2007; Fung, Gul, \& Krishnan, 2012); (2) em firmas que procuram criar times de especialistas em nível global, com embasamento em conhecimentos de negócio e treinamentos específicos em determinado setor (Carson, 2009); e (3) na avaliação de risco ${ }^{11}$ (Taylor, 2000).

A especialização se relaciona com a vantagem competitiva através da curva de aprendizagem. O conceito psicológico demonstra que o nível de conhecimento de especialista é obtido através da experiência prática. Quando aplicados ao conceito de auditoria, são essenciais o portfólio de clientes no mesmo segmento, a composição do quadro de funcionários com conhecimento sobre esse setor, o investimento em tecnologia e a criação de processos organizacionais, a fim de o auditor especialista estar mais apto a detectar irregularidades, comparativamente ao auditor não especialista (Balsam, Krishnan, e Yang, 2003; Simunic \& Stein, 1987). Vale ressaltar que a especialização em um setor específico afere qualidade da auditoria tanto na contratação do serviço (ex ante), quanto na emissão do relatório (ex post).

\footnotetext{
${ }^{11}$ Taylor pesquisou a avaliação dada por dois grupos, sendo um formado por especialistas no setor bancário e outro formado por especialistas em outros setores, sobre um caso no setor bancário. Os resultados de sua pesquisa demonstraram que os auditores não bancários assumem riscos maiores do que os auditores especialistas no setor bancário. Assim sendo, a especialização pode ser considerada uma variável significativa para o planejamento da auditoria (Taylor, 2000).
} 
O investimento para obtenção do conhecimento e reputação em um setor específico, no entanto, deve atingir o ponto de equilíbrio entre os custos mitigáveis. Uma auditoria com alta especialização em um setor específico arcará com mais custos com colaboradores e conhecimento do que uma auditoria não especialista (Keefe et al., 1994).

\subsubsection{Audit delay}

O audit delay pode ser descrito como o prazo entre o fim do ano fiscal e o fim do trabalho de campo da auditoria (comumente referenciado como a data consignada no parecer de auditoria). Assim sendo, os auditores realizam procedimentos mais extensos em empresas com fraca situação patrimonial, e isso faz com que o prazo do reporte seja maior.

Ashton, Willingham e Elliot (1987) pesquisaram a relação do audit delay com variáveis que representavam a empresa, o auditor e outras interações dessas partes. Como resultado, identificaram que o atraso no parecer é significativamente maior nos casos de empresas que receberam opiniões modificadas no parecer e nos casos de empresas que possuem controles internos falhos. Em consonância com esses resultados, Kinney e McDaniel (1993) detectaram que o controle interno falho é um forte determinante para o audit delay. A possibilidade de erros na contabilidade e dúvidas acerca da continuidade da empresa também foram detectadas como possíveis motivos para um maior tempo no parecer de auditoria (Kinney \& McDaniel, 1993).

Em estudo acerca do mercado de Hong Kong, Jaggi e Tsui (1999) trouxeram evidências de que o audit report delay ocorre em função de riscos para os auditores e tecnologias das empresas de auditoria. Os riscos de auditorias estão fortemente relacionados com o aparato teórico da existência de quase-rendas e dos custos políticos. O uso de tecnologia está associado tanto à melhoria dos controles internos das empresas (Masli, Peters, Richardson, \& Sanchez, 2010), quanto à melhoria tecnológica dos processos de auditoria (Newton \& Ashton, 1999; Cushing, 1989). 
Portanto, mostra-se necessária a utilização do audit delay como um determinante de possíveis problemas de qualidade da auditoria (Braunbeck, 2010), tal qual utilizado em outros estudos empíricos. $^{12}$

\subsubsection{Tamanho da auditoria}

Mesmo entre duas firmas com idênticas capacidades tecnológicas, o tamanho é considerado um determinante da qualidade da auditoria (DeAngelo, 1981b). Portanto, o tamanho da firma mitiga outros aspectos, como audit delay e as quase-rendas de clientes específicos ${ }^{13}$.

Alguns estudos empíricos utilizam como proxy de qualidade a variável tamanho das quatro maiores firmas de auditoria. Knechel, Naiker e Pacheco (2007) pesquisaram o efeito da troca de auditor para uma firma reconhecida como especialista no setor e sua associação no preço da ação da empresa, demonstrando que há aumento no valor e que um dos motivos é a valorização do tamanho da nova firma de auditoria e de sua marca.

Geiger e Rama (2006) pesquisaram se as empresas auditadas por alguma das quatro maiores possuem mais qualidade e menos erros nos reportes, no contexto de relatório com ressalva por descontinuidade (going concern modified reports). Os autores examinaram os dois tipos de erros possíveis: (I) posição modificada em um cliente que se mantém operacional e (II) opinião não modificada em um cliente que subsequentemente entra em processo de falência. Como resultado, percebe-se que ambos os tipos de erros são significativamente inferiores nas empresas auditadas pelas quatro maiores firmas de auditoria, em comparação com as demais (Geiger \& Rama, 2006).

12 As legislações que estabelecem limite para apresentação das Demonstrações Financeiras são a Lei de Falências e a Lei $\mathrm{n}^{\circ}$ 6.404/76, que no seu art. 133 determina o prazo limite de 30 (trinta) dias antes da Assembléia Geral Ordinária (AGO) para que as Demonstrações Financeiras sejam disponibilizadas pelos administradores aos membros da AGO. Sendo a data limite para a realização da AGO 30 de abril do ano subsequente, subentende-se que o prazo limite para fechamento das Demonstrações Contábeis é 31 de março do ano subseqüente, ou 90 dias após a data de fechamento anual.

13 DeAngelo (1981b) demonstra os efeitos da quase-renda no portfólio de uma empresa de auditoria, demonstrando que quanto maior for este, menor será a tendência de a firma não reportar uma falha encontrada. Outro fator elaborado se destaca na remuneração dos sócios da firma de auditoria. O argumento se baseia no fato de que tendo um portfólio diversificado e uma remuneração baseada na proporção dos lucros da firma, há menor dependência em reter um determinado cliente, além de diminuição dos custos de agência entre o sócio e a firma de auditoria. 
Portanto, mostra-se necessária a utilização do tamanho da auditoria como um determinante de possíveis problemas de qualidade da auditoria, tal qual utilizado em estudos empíricos sobre a qualidade da auditoria.

\subsection{Qualidade da contabilidade}

De acordo com Watts e Zimmerman (1986), a discrição na contabilidade pode ser utilizada para fins oportunistas e possivelmente gerar interpretações errôneas sobre o desempenho econômico de uma entidade; porém, as informações contábeis podem ser utilizadas ao se revelar informações sobre a companhia.

Nesse sentido, Barth et al. (2008) definem como métricas para a mensuração da qualidade da informação contábil o gerenciamento de resultados, o reconhecimento tempestivo de perdas e a value relevance. $\mathrm{O}$ gerenciamento de resultados pode ser conceituado como a alteração proposital, pelos gestores, dos resultados contratuais que dependem do reporte contábil, com o intuito de ludibriar os demais interessados (Healy e Wahlen, 1999; Chen et al., 2010). Para este estudo, serão utilizadas duas das métricas mencionadas por Barth et al. (2008): gerenciamento de resultado seguindo a meta e reconhecimento tempestivo de perdas.

A primeira dessas duas métricas demonstra a tendência das empresas para gerenciar prejuízo em pequenos lucros, sendo, assim, indicador de baixa qualidade da contabilidade. Enquanto isso, a segunda se relaciona ao fato de que o reconhecimento de grandes perdas reflete uma alta qualidade da contabilidade (Barth et al., 2008; Chen et al., 2010). O reconhecimento de grandes perdas, como métrica de qualidade da contabilidade, é mais comum em companhias sob o sistema jurídico contábil baseado na forma jurisprudencial (Dechow, Ge, \& Schrand, 2010).

As mencionadas métricas demonstram o efeito do conservadorismo nas demonstrações contábeis. Basu (1997) interpreta o conservadorismo como o reconhecimento das "más noticias" mais rapidamente que as "boas noticias"; ou seja, os resultados contábeis relacionados às más notícias são reconhecidos mais tempestivamente que aqueles atrelados às boas notícias. De acordo com Dechow et al. (2010), as métricas supramencionadas 
demonstram o conservadorismo condicional, em vez do conservadorismo incondicional, que procura estudar as políticas prévias de uma companhia que visam à diminuição dos valores dos ativos (ou aumento de passivos) buscando conservadorismo da gestão. Portanto, espera-se que a maior qualidade da contabilidade gere diminuição do gerenciamento de resultados e aumento do reconhecimento tempestivo das perdas, através do conservadorismo condicional de uma companhia.

Dechow et al. (2010) pesquisaram se o reconhecimento temporal de ganhos e perdas, sem a distinção pelo efeito no caixa, possui maior carga informativa do que o regime de fluxo de caixa. Eles definem, no entanto, que a afirmativa anterior é apenas uma suposição baseada em algumas atividades do negócio. Os autores defendem que a suavização de resultados pode ser mais informativa em mercados sem escolhas contábeis, pois as escolhas contábeis de uma companhia podem oportunamente motivar, e não melhorar, a decisão sobre a $o$ reconhecimento pela competência dos resultados.

Relações entre qualidade da auditoria e qualidade da contabilidade foram exploradas anteriormente. Hribar et al. (2010) desenvolveram um método de mensuração de qualidade da contabilidade através dos honorários de auditoria.

Utilizando preceitos teóricos do processo de auditoria, adjacentes a esta pesquisa (e.g., quaserendas), os autores defendem que ao detectar uma baixa qualidade da contabilidade, os auditores irão aumentar suas necessidades de testes complementares e demandarão maiores honorários de auditoria. Eles concluem que os honorários de auditoria são positivamente correlacionados a métricas de "earnings quality" e que possuem carga preditiva da republicação de balanços, fraudes e cartas-comentário da SEC no mercado norte-americano.

\subsection{O relatório de auditoria}

À luz do processo de auditoria como uma das formas de enforcement e de controle sobre a contabilidade de uma empresa, a formação da opinião de um auditor é de suma importância. Sunder (1997) relata que, em troca de uma taxa de auditoria, o auditor aceita certas responsabilidades sobre a veracidade das demonstrações financeiras e de sua divulgação, de modo que as demonstrações financeiras são frequentemente auditadas pelos auditores independentes com o propósito de acrescer confiabilidade às informações nelas contidas. 
O papel dos auditores independentes se materializa, em sua fase final, com a emissão do relatório destes, que deve conter uma opinião sobre as demonstrações contábeis de uma entidade em determinado período. Essa opinião consiste na conclusão apresentada no relatório de auditoria, podendo ser expressa como opinião não modificada (também referida como sem modificações ou, de forma mais vulgar, como "opinião limpa") ou opinião modificada.

A opinião não modificada é expressa pelo auditor quando ele conclui que as demonstrações financeiras foram elaboradas, em todos os aspectos relevantes, de acordo com a estrutura de relatório financeiro aplicável, enquanto a opinião modificada compreende opinião com ressalva, adversa ou abstenção de opinião. A opinião do auditor pode ser modificada, caso haja (I) inconsistência nos métodos contábeis, (II) problemas no escopo do trabalho de auditoria ou (III) incerteza associada, principalmente, a contingências não resolvidas (Sunder, 1997).

Assim, no final das negociações entre a empresa e a firma de auditoria, o auditor escolhe a opinião considerada mais apta à empresa e avalia suas consequências (quase-rendas). Os quesitos que possam influenciar a opinião do auditor são objeto de estudo de vários autores. Em cenários adversos de um cliente, por exemplo, a modificação de opinião do auditor poderá mitigar seus riscos com potenciais litígios (Mong \& Roebuck, 2005). Na visão de mercado, a modificação de opinião pelo auditor tem o potencial de afetar a expectativa de retornos, ao sinalizar que o gerenciamento de resultados é nocivo ou traz resultados menos persistentes (ou os dois) para os investidores (Chen, Su. \& Zhao, 2000).

Sobre earnings management, descritos e pesquisados na qualidade da contabilidade por este estudo, Bradshaw, Richardson e Sloan (2001) detectaram que o auditor pode acreditar em uma possível violação de prática contábil ou gerenciamento de resultados por uma companhia; no entanto, ele não é requerido a informar aos investidores tais eventos via opinião no relatório de auditoria. Herbohn e Ragunathan (2008) confirmam a visão desses autores, e afirmam que uma condição necessária ao gerenciamento de resultados é a não detecção por usuários externos; ou seja, as escolhas contábeis são feitas de acordo com as práticas contábeis. Butler, Leone e Willenborg (2004) demonstram uma associação positiva 
entre gerenciamento de resultados negativos e a opinião do auditor com ressalva por descontinuidade operacional. Enquanto isso, Herbohn e Ragunathan (2008) demonstram que a modificação de opinião do auditor, nesse cenário, não é aferida por potencial gerenciamento de resultado.

Fatores externos ao processo de auditoria também podem influenciar a opinião do auditor. Através de um experimento, Joe (2003) pesquisou o efeito de informações externas sobre o julgamento de um auditor independente. A autora concluiu que o auditor estará mais suscetível a emitir uma opinião com modificação de opinião se a cobertura da imprensa detectar uma informação negativa, e redundante, a informações que estes já possuíam anteriormente.

\subsection{Teorias da qualidade da auditoria e da contabilidade}

O referencial desta pesquisa buscou agregar estudos nos principais periódicos internacionais acerca da qualidade da auditoria ex ante ao parecer do auditor independente a da contabilidade da entidade auditada. Na seção seguinte, será explorado o desenho da pesquisa, constando as variáveis construídas para detectar as teorias e seus sinais esperados. Como objetivo da pesquisa, buscou-se detectar as influências das teorias analisadas nesta seção e a opinião do auditor; sendo esta com, ou sem, modificação de opinião no relatório de auditoria.

Tabela 1 - Resumo teorias da qualidade da auditoria e da contabilidade

\begin{tabular}{l|l|l|}
\hline Teoria & Fatores & \multicolumn{2}{l}{ Resumo } \\
\hline $\begin{array}{l}\text { Qualidade da } \\
\text { Contabilidade } \\
\text { pequenos lucros }\end{array}$ & $\begin{array}{l}\text { Reconhecimento de } \\
\text { grandes perdas }\end{array}$ & $\begin{array}{l}\text { Evidencia a disposição da firma auditada em gerir resultado } \\
\text { para atingimento de metas, reflexo da decisão da administração } \\
\text { em gerenciar resultados. } \\
\text { Evidencia a disposição da firma auditada em reconhecer } \\
\text { perdas quando incorridas, reflexo da decisão da administração } \\
\text { em não gerenciar os resultados. }\end{array}$ \\
\hline $\begin{array}{l}\text { Qualidade da } \\
\text { Auditoria }\end{array}$ & $\begin{array}{l}\text { Evidencia o custo de oportunidade do auditor, reflexo da } \\
\text { escolha em auditar um cliente específico. } \\
\text { Evetorialização no } \\
\text { Evidencia o conhecimento do auditor em um setor específico } \\
\text { da economia, reflexo de investimentos e reputação. } \\
\text { Evidencia o atraso na emissão do relatório de auditoria pelo } \\
\text { auditor, reflexo de possíveis problemas nas demonstrações } \\
\text { financeiras da firma auditada. } \\
\text { Evidencia a reputação e capacidade do auditor, reflexo de } \\
\text { portfolio de firmas auditadas mais robusto que suas concorrentes } \\
\text { menores. }\end{array}$ \\
\hline
\end{tabular}




\section{DESENHO DA PESQUISA}

Martins e Theóphilo (2009) explicitam a dependência de fundamentação teóricometodológica que orienta o pesquisador. A elaboração do libby box e o embasamento do conceito dentro de um marco teórico auxiliaram no alicerce desta pesquisa. Esse método é proposto para pesquisas empíricas, e auxilia na elaboração do research design de modo eficiente e efetivo (Libby, Bloomfield, \& Nelson, 2002).

A fim de viabilizar a exploração do conceito teórico no âmbito da empiria, foi elaborado um construto como definição operacional, que procura representar empiricamente um conceito dentro de um marco teórico. Assim sendo, para se viabilizar o teste empírico que possibilite a identificação dos principais fatores da opinião contida no relatório de auditoria, cabe a elaboração desse construto, o que se faz através de um libby box.

O libby box auxilia na elaboração e no teste das hipóteses de pesquisa, através de cinco etapas: Etapa 1 - teoria e hipóteses: esta etapa objetiva a ligação do conceito teórico a ser detectado com outros conceitos adjacentes. Assim sendo, esta é a etapa que objetiva a definição de uma hipótese de pesquisa eficiente. Essa hipótese, tal qual demonstrado por Libby et al. (2002), deve possuir validade externa, ou seja, a relação entre as teorias conceituais capturadas e o aspecto a ser estudado deve ser crível; Etapas 2 e 3 operacionalização das variáveis dependentes e independentes: esta etapa consiste na transformação de uma teoria-base em variáveis que objetivam capturar o efeito do referencial teórico; a etapa consiste no levantamento teórico e na revisão da literatura; Etapa 4 - métodos estatísticos: o desenho da pesquisa objetiva a definição do melhor aparato estatístico que irá identificar a relação referida na Etapa 1; Etapa 5 - variáveis de influência ou controle. 
Figura 2 - Estrutura da validade preditiva - parecer de auditoria

\begin{tabular}{|c|c|c|c|}
\hline \multirow{4}{*}{ Teoria } & $\begin{array}{c}\text { Variável } \\
\text { Independente }\end{array}$ & \multirow{2}{*}{1} & $\begin{array}{c}\text { Variável } \\
\text { Dependente }\end{array}$ \\
\hline & X Conceitual & & Y Conceitual \\
\hline & $\begin{array}{c}\text { Qualidade da } \\
\text { contabilidade (QC) } \\
\text { Qualidade da } \\
\text { auditoria (QA) }\end{array}$ & \multirow[b]{4}{*}{4} & Relatório da auditoria \\
\hline & 2 & & 3 \\
\hline \multirow{5}{*}{ Operacional } & X Operacional & & Y Operacional \\
\hline & $\begin{array}{l}\text { [QCi] Gerenciamento } \\
\text { de resultados } \\
\text { seguindo a meta } \\
\text { [QCii] Reconhecimento } \\
\text { de grandes perdas }\end{array}$ & & $\begin{array}{l}\text { Variável de natureza } \\
\text { dicotômica (opinião do } \\
\text { auditor): } \\
\text { Parecer limpo: } 1 \\
\text { Parecer modificado: } 0\end{array}$ \\
\hline & $\begin{array}{l}\text { [QA i] Market share } \\
\quad \text { (audit) }\end{array}$ & & 5 \\
\hline & $\begin{array}{l}\text { [QA ii] Market share } \\
\quad \text { (sector) }\end{array}$ & & Variáveis de controle \\
\hline & $\begin{array}{l}\text { [QA ii] Especialização } \\
\text { [QA iii] Audit delay } \\
\text { [QA iv] Big-N }\end{array}$ & & $\begin{array}{l}\cdot \text { Leverage } \\
\cdot \text { PLdummy } \\
\cdot \text { LLdummy }\end{array}$ \\
\hline
\end{tabular}

\subsection{Método}

Para o objetivo deste estudo, enquadrado e explorado no libby box, detectou-se que a variável dependente é binomial (parecer modificado ou parecer limpo / sem modificação), e se espera, através das variáveis independentes de qualidade, tanto de auditoria quanto de contabilidade, um modelo de estimação do parecer de auditoria. Dentre as companhias analisadas, existem diferenças e semelhanças; portanto, há a necessidade de estatística para junção das 
companhias em grupos menores, a fim de se sintetizar a análise. Assim sendo, foram utilizadas as seguintes ferramentas estatísticas:

i. Regressão logística binomial (logistic regression): Segundo Fávero, Belfiore, Silva e Chan (2009), a técnica estatística de regressão logística binomial é utilizada para descrever o comportamento de uma variável dependente binária e variáveis independentes métricas ou não métricas. Essa regressão assume as seguintes premissas:

a) relação linear entre o vetor das variáveis explicativas $\mathrm{X}$ e a variável dependente $\mathrm{Y}$;

b) o valor esperado dos resíduos é igual a zero;

c) ausência de autocorrelação;

d) ausência de correlação entre os resíduos e as variáveis explicativas; e

e) ausência de multicolinearidade.

Fávero et al. (2009) simplificam a função logística determinando-a como probabilidade de a variável dependente ser equivalente a 1, dado o comportamento das variáveis independentes. Assim sendo, a Equação 8 refletirá a base estatística para análise e exploração da estimação dos relatórios de auditoria.

$$
\begin{aligned}
& \operatorname{prob}(\text { event })=\frac{1}{1+e^{-(Z)}} \\
& Z=\propto+\sum \beta_{i} X_{i}
\end{aligned}
$$

Sendo:

No tocante à divulgação dos resultados, Wooldridge (2009) ressalta que devem ser publicados em estudos que utilizam o método logit nos seguintes outputs sistêmicos: $(\beta)$ coeficiente de estimação, erro padrão (neste estudo utilizaremos também o p-value para a significância estatística) e o valor do log-likelihood. 
ii. Análise de cluster e análise multidimensional: As duas técnicas serão utilizadas para exploração das fusões e junções dos setores, objetivando analisar visualmente os resultados obtidos na regressão logística. A análise de cluster produz um dendrograma por setor. Enquanto isso, a análise multidimensional representa os dados como uma configuração dos setores em duas dimensões e demonstra uma análise gráfica das diferenças entre os setores. As análises exploratórias possibilitarão detectar as fusões entre os setores com especificidade e sensibilidade próximas, demonstrando possíveis variáveis a serem analisadas.

\subsection{Amostra}

A população utilizada compreende relatórios de auditoria de 1998 a 2012 de companhias abertas brasileiras. A seleção da amostra se deu por exclusão de empresas em períodos nos quais há falta de informações; trata-se, portanto, de uma amostra não probabilística por conveniência. De uma população de 5.737 relatórios de auditoria, foram excluídos 1.626, sendo 940 que não continham informações sobre o período anterior (não há possibilidade de calcular variáveis como ROA com delay) e 686 que não continham informações sobre a receita da companhia em algum ou alguns períodos. A amostra ficou definida em 4.111 empresas, cobrindo o período de 1999 a 2012, sendo que 58,8\% dos pareceres foram emitidos sem modificação. Assim, pretendeu-se, de maneira exploratória, buscar indicadores para responder à questão de pesquisa. Devido ao fato de a amostra ser não probabilística por conveniência, as conclusões deste estudo se restringem à amostra selecionada.

\subsection{Modelo}

Vis-à-vis o construto teórico embasado e explorado na estrutura preditiva do libby box, este estudo procura detectar a associação do parecer de auditoria com métricas de qualidade da contabilidade e de auditoria. A Equação 10 foi construída através da pesquisa teórica, e as relações entre suas variáveis independentes são expostas na Tabela 1.

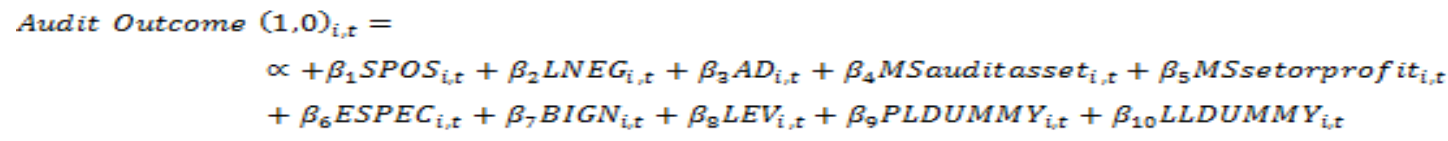


Tabela 2 - Construto de variáveis independentes

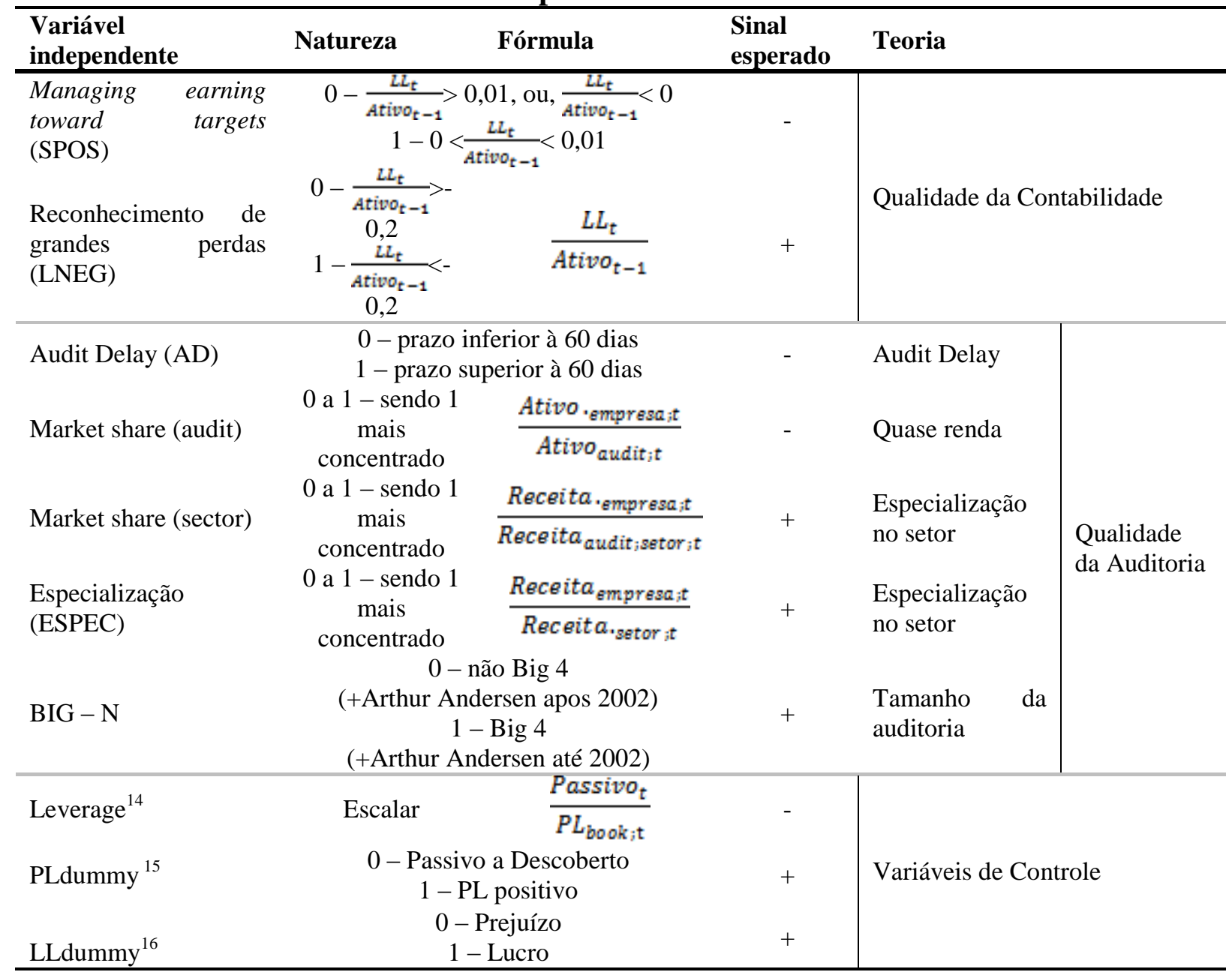

Partindo-se da citada amostra, faz-se necessária uma análise descritiva das variáveis do modelo. A análise descritiva procura identificar o comportamento das variáveis estudadas e compreender de maneira preliminar seus comportamentos. A fim de se minudenciar as

\footnotetext{
${ }^{14}$ Leverage (Endividamento): retrata a razão entre a dívida de curto e longo prazos da entidade e seu patrimônio líquido contábil (book) em determinado período. Espera-se, de acordo com construto teórico, que quanto maior o nível de endividamento de uma companhia, maior a probabilidade de o parecer possuir opinião modificada. Pois nesse contexto haverá mais exigência dos auditores em relação às suas quase-rendas.

15 PLdummy (Passivo a Descoberto): variável binária que procura identificar companhias em situação de descontinuidade operacional. Estima-se que as companhias auditadas com patrimônio líquido negativo tenham mais probabilidade de obter parecer de auditoria sem modificação de opinião.

${ }^{16}$ LLdummy (Prejuízo): variável binária que detecta firmas com prejuízo líquido em determinado período. Espera-se uma relação direta entre essa variável e a qualidade da contabilidade de uma companhia.
} 
variáveis teóricas expostas no libby box, a variável dependente e as variáveis independentes (qualidade da contabilidade e qualidade da auditoria) serão exploradas em mais detalhes.

Tabela 3 - Estatísticas básicas das variáveis

\begin{tabular}{lcccc}
\hline VARIÁVEL & MÉDIA & MEDIANA & $\begin{array}{c}\text { DESVIO- } \\
\text { PADRÃO }\end{array}$ & $\begin{array}{c}\text { COEFICIENTE } \\
\text { DE VARIAÇÃO }\end{array}$ \\
\hline PROB (Audit Outcome) & 0,5877 & 0,6411 & 0,2633 & 0,4480 \\
SPOS & 0,0684 & 0 & 0,2524 & 3,6901 \\
LNEG & 0,0888 & 0 & 0,2845 & 3,2038 \\
Audit Delay (dias) & 67 & 62 & $\mathrm{n} / \mathrm{a}$ & $\mathrm{n} / \mathrm{a}$ \\
Audit Delay & 0,5198 & 1 & 0,4997 & 0,9613 \\
Msaudit_ativo & 0,1418 & 0,0064 & 0,3036 & 2,1410 \\
Mssector_receita & 0,4467 & 0,2859 & 0,4053 & 0,9073 \\
ESPEC & 0,0635 & 0,0174 & 0,1253 & 1,9732 \\
BIG - N & 0,6553 & 1 & 0,4753 & 0,7253 \\
Leverage & 1,7482 & 0,5787 & 14,8753 & 8,5089 \\
PLdummy & 0,8808 & 1 & 0,3241 & 0,3680 \\
LLdummy & 0,6745 & 1 & 0,4686 & 0,6947 \\
\hline
\end{tabular}

A seguir, são exploradas e identificadas com mais detalhamento as variáveis do construto de variáveis independentes.

\subsubsection{Relatório de auditoria}

Tal qual apresentado na plataforma teórica, o resultado do trabalho dos auditores independentes se materializa com a emissão do seu relatório, que deve conter uma opinião sobre as demonstrações contábeis de uma entidade em um determinado período. Essa opinião consiste na conclusão apresentada no relatório de auditoria, e será analisada estatisticamente como opinião não modificada $(n=2.416)$ ou opinião com modificação de opinião, tendo como motivo de modificação abstenção de opinião $(n=28)$, opinião com ressalva $(n=364)$, opinião adversa $(n=7)$, opinião com ênfase $(n=1.177)$ ou limitação de escopo $(n=119)$. 
Figura 3 - Evolução do parecer de auditoria - 1999/2012

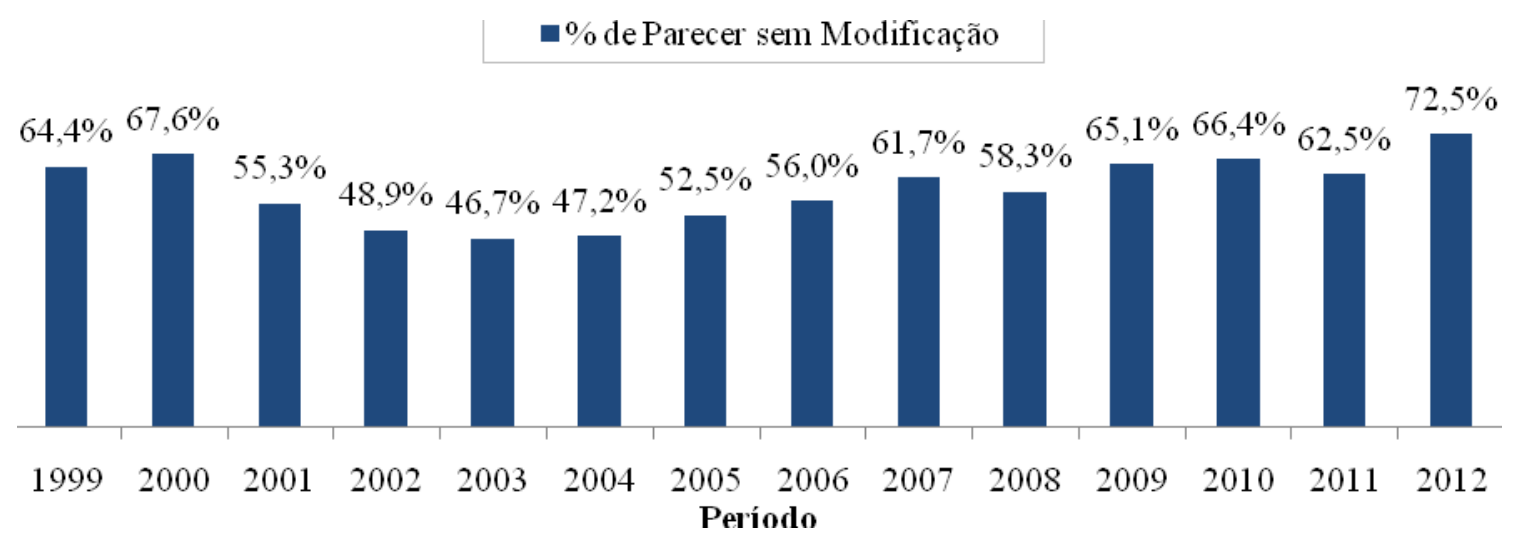

$\mathrm{Na}$ análise descritiva, corroborada com o demonstrado na Figura 3, percebe-se que, no tocante à amostra do estudo, não há um período com grande disparidade de pareceres com opinião modificada.

\subsubsection{Qualidade da contabilidade}

Foram utilizadas duas variáveis relacionadas à qualidade da contabilidade. A primeira se refere ao gerenciamento de resultado, o qual demonstra a tendência das empresas para gerenciar prejuízo em pequenos lucros (SPOS), levando a uma baixa qualidade da contabilidade, tal qual apresentado na Figura 4.

A segunda variável se relaciona ao fato de que o reconhecimento de grandes perdas (LNEG) reflete uma alta qualidade da contabilidade. No entanto, a amostra estudada apresenta uma quantidade superior de empresas com grandes perdas. Dentre os 365 eventos que apresentaram essa situação, $88 \%$ dos pareceres continham alguma forma de modificação de opinião, demonstrando uma possível limitação na utilização da variável de reconhecimento de grandes perdas (LNEG). 


\section{Figura 4 - Comportamento de variáveis da qualidade da contabilidade}

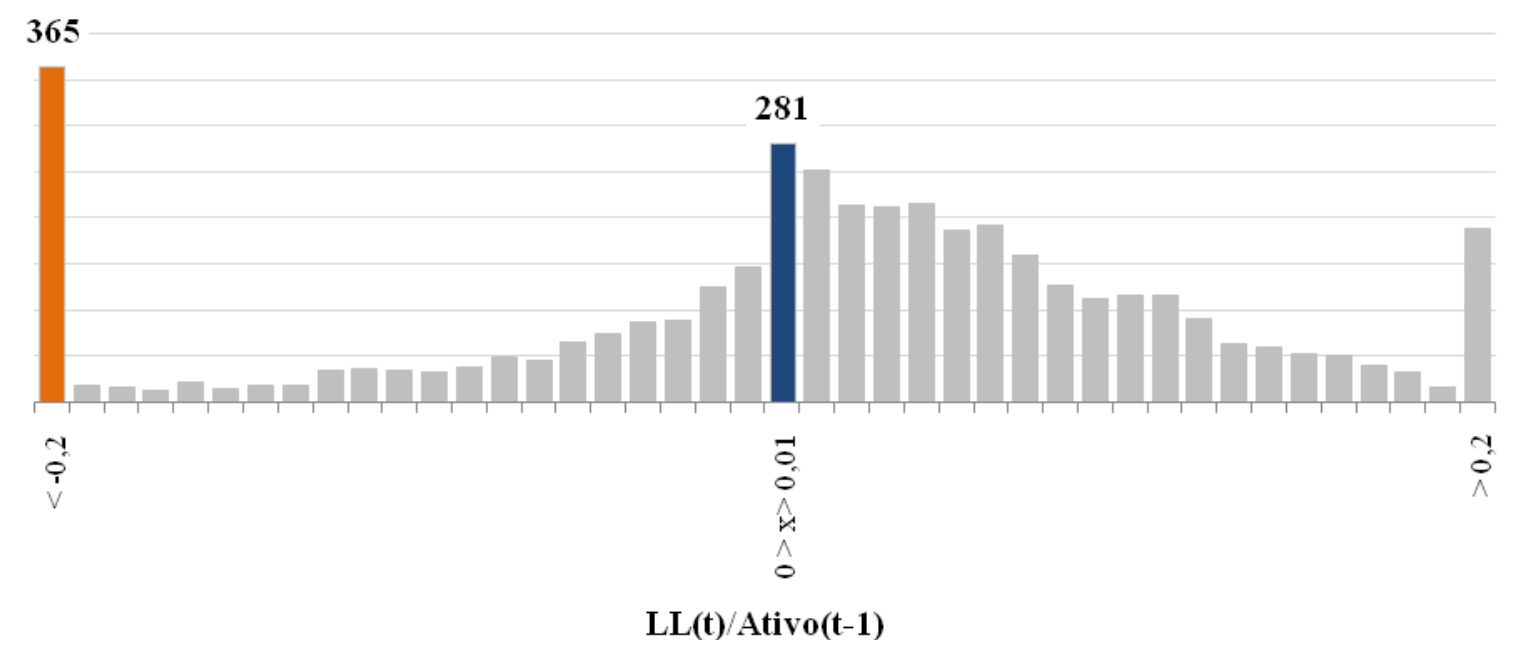

\subsubsection{Qualidade da auditoria}

\subsubsection{Audit delay}

A análise da amostra no tocante aos prazos para emissão de relatórios de auditoria evidencia uma mediana de 62 dias. A fim de se alinhar a presente pesquisa com outros estudos empíricos, a emissão do parecer de auditoria em prazo superior a 60 dias após o encerramento das demonstrações contábeis foi considerada um indício de audit delay. Essa variável binária é utilizada como indicador de detecção de possível problema na negociação entre empresa e firma de auditoria. No entanto, essa não é a única determinante potencial de audit delay, mas, sim, a mais comumente utilizada, e, para tanto, pressupõe-se que as companhias abertas, de forma generalizada, possuem incentivos para a pronta divulgação de seus relatórios financeiros (Braunbeck, 2010).

\subsubsection{Reputação/competência - quase-renda}

Seguindo o objetivo de estimação (DeAngelo, 1981a) do parecer de auditoria, detectou-se como possível métrica a relação entre os ativos de determinada empresa e o total de ativos auditados por sua empresa de auditoria, por se tratar do tamanho de determinada empresa no portfólio da firma de auditoria. A relação entre as receitas de determinada empresa e o total de receitas das empresas auditadas por sua auditora se percebe como métrica alternativa. No entanto, há elevada colinearidade entre as variáveis de quase-renda que captam o ativo e aquelas que se baseiam na receita. 
Figura 5 - Comportamento da variável quase-renda

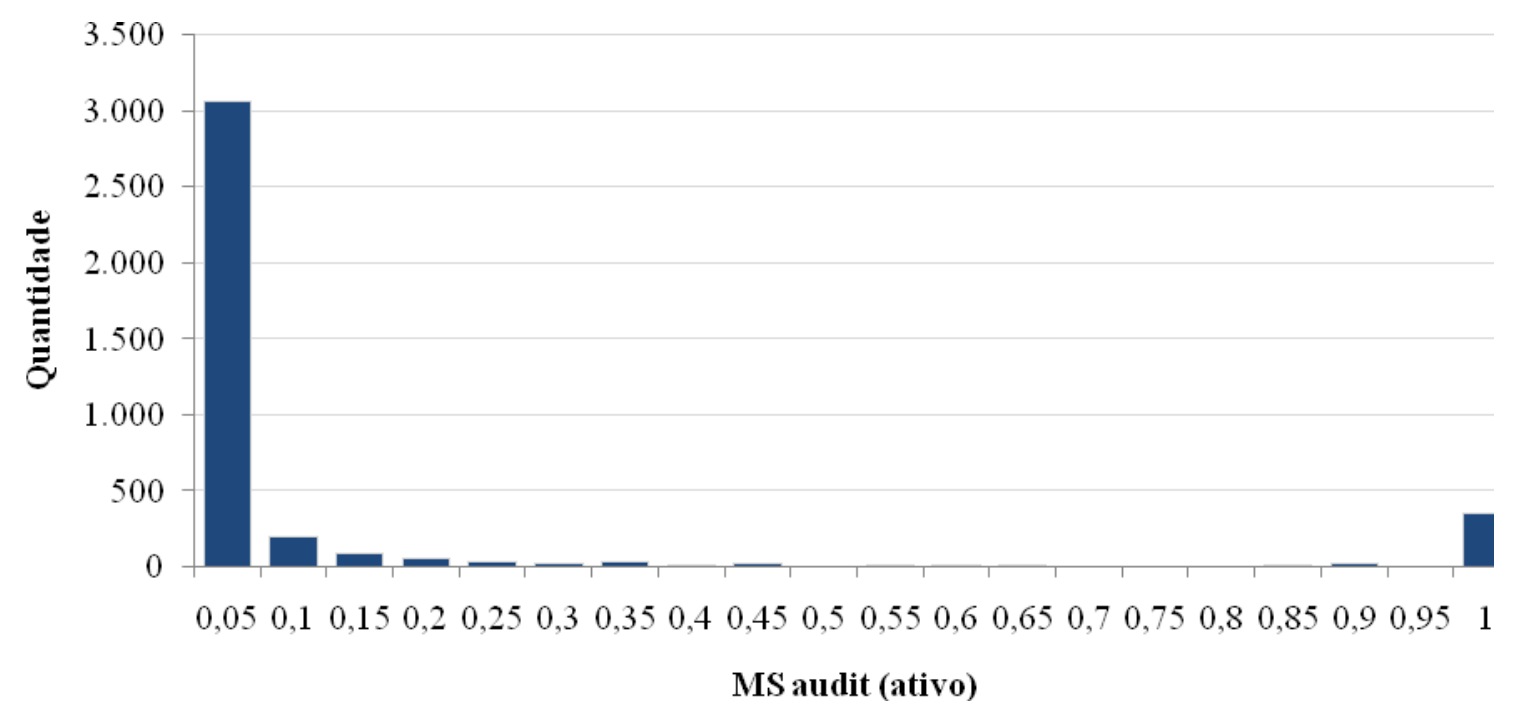

A Figura 5 demonstra que $75 \%$ da amostra possui baixa dependência, representada pelos valores inferiores a 0,05 . Para a cauda à direita da figura, $8 \%$ das empresas possuem firma de auditoria sem portfólio. De acordo com o embasamento teórico, espera-se que a firma de auditoria ceda às quase-rendas e emita parecer sem modificação de opinião. No entanto, $75 \%$ dos pareceres possuíam alguma forma de modificação de opinião.

\subsubsection{Especialização no setor}

A lista de pesquisas sobre especialização de auditores é extensa. No entanto, as metodologias utilizadas ainda não estão definidas. Neal e Riley (2004) exploram duas abordagens de métrica da especialização de uma firma em determinado segmento: market share e portfólioshare. A abordagem do market share analisa o quanto uma firma se diferencia de seus competidores, em termos de participação no mercado, em determinado segmento. Enquanto isso, o portfólio-share é definido pelos autores como a distribuição dos serviços de determinada firma de auditoria e seus fees dentro de várias indústrias.

No sentido de captar o efeito da especialização, ambas as abordagens serão utilizadas. Vale ressaltar a falta de divulgação acerca dos honorários de auditoria no Brasil e a escassez de pesquisas nesse ramo. Portanto, métricas com essa variável demandam estudo. 
Para a captura do efeito market share, pretende-se utilizar a relação entre as receitas de determinada empresa sobre o total de receitas auditado por sua empresa de auditoria dentro do setor. Na abordagem do portfólio, a métrica comumente utilizada como especialização de uma empresa no setor é a relação entre a receita da empresa e o total das receitas do setor.

\section{Figura 6 - Comportamento variáveis especialização no setor}

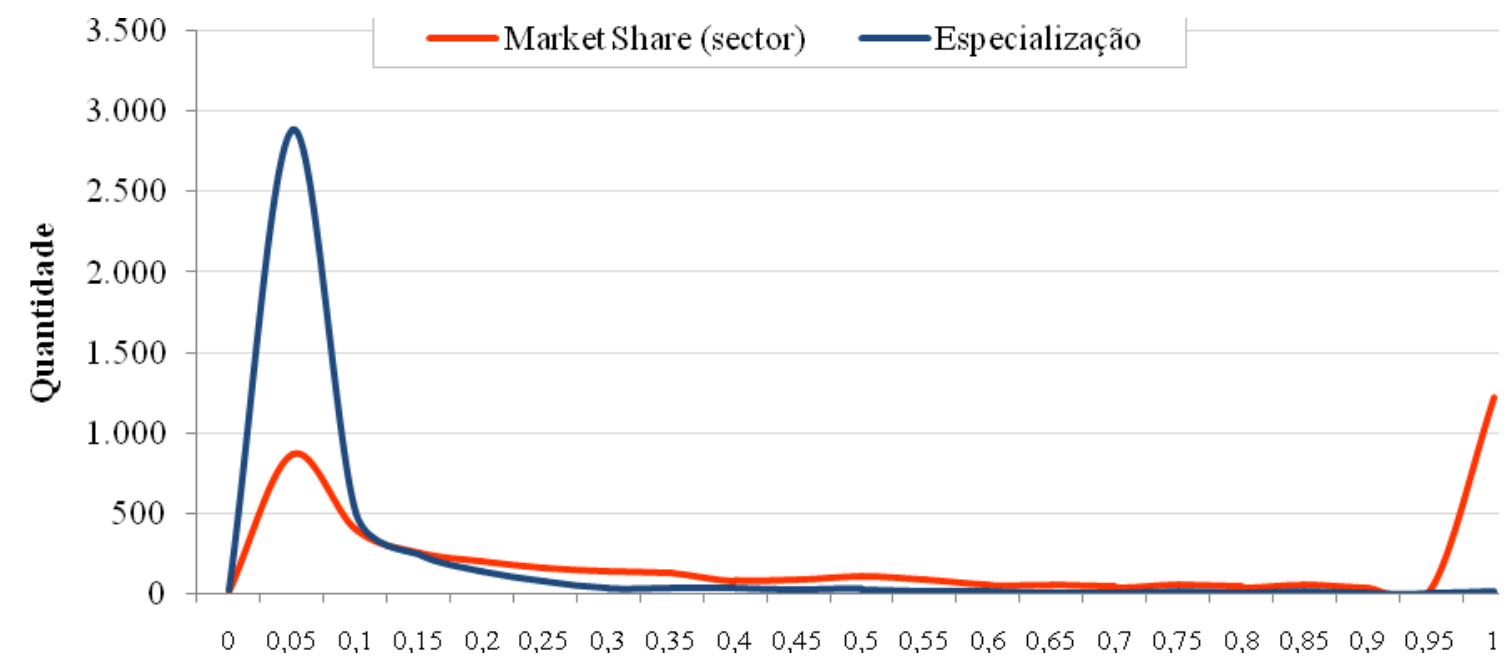

A abordagem do portfólio, para o mercado brasileiro, aparenta ser mais forte. Essa métrica possui forte relação com o tamanho da empresa sobre o mercado, e com o know-how da firma sobre as práticas contábeis. A métrica do market share possui diferenciação com a proxy de quase-renda utilizada neste estudo, devido ao fato de existirem empresas inseridas em mercados com baixa margem de lucro, o que poderá acarretar altas receitas e baixa quantidade de ativos. Tal qual apresentado na análise descritiva da métrica de quase-renda, a relação de market share possui cauda à direita com altas quantidades. Assim sendo, a relação proposta de receita de uma empresa sobre o total de receitas auditadas pela firma de auditoria se evidencia como métrica alternativa à relação de quase-renda.

\subsubsection{Tamanho da auditoria}

O portfólio das grandes firmas de auditoria no Brasil equivale, em sua maioria, a empresas de grande porte. De acordo com o embasamento teórico, os auditores maiores têm reputação a perder em casos de "escândalos", e, portanto, possuem incentivos para manter a qualidade da auditoria superior à dos seus concorrentes. 
Tabela 4 - Firma de auditoria e empresas de grande porte

\begin{tabular}{lcc}
\hline Firma/Empresa & PME & Grande Porte a \\
\hline Pequena Firma de Auditoria & 655 & 1.040 \\
BIGN & 430 & 1.986 \\
\hline Total & 1.085 & 3.026 \\
\hline a De acordo com a lei 11.638/2007, empresa de grande porte é aquela com ativo superior a R $\$ 240$ milhões ou \\
receita bruta anual superior a $\mathrm{R} \$ 300$ milhões.
\end{tabular}

O termo BIGN é utilizado em estudos empíricos para definir as grandes firmas de auditoria. São classificadas as seguintes firmas de auditoria: Arthur Andersen (até 2002, devido a seu colapso na crise Enron), Deloitte, Ernst \& Young (E\&Y), KPMG e PricewaterhouseCoopers (PwC).

\subsubsection{Setores analisados}

Utilizou-se para agrupação dos setores da amostra a classificação Economática ${ }^{\circledR}$. A classificação proposta engloba 21 setores econômicos. Dentre a população, foram analisados apenas 20 setores. O setor econômico finanças e seguros foi descartado pela suspensão da rotatividade das firmas de auditoria após a Resolução do Conselho Monetário Nacional $\mathrm{n}^{\circ}$ 3.505/2007, podendo gerar análises dispares às apresentadas nos outros setores e sendo necessária análise específica.

Segue abaixo descrição da operação das empresas constantes nos setores analisados:

- Alimentos e Bebidas: empresas atuantes na produção e distribuição de carnes, laticínios, cerveja, dentre outros produtos perecíveis.

- Transportes e Serviços: empresas atuantes no serviço de transporte de passageiros e cargas por vias rodoviárias, ferroviárias e aéreas; além de companhias atuantes em concessões rodoviárias.

- Siderurgia e Metalurgia: empresas atuantes na produção de metal.

- Construção: empresas atuantes no setor de construção imobiliária.

- Papel e Celulose: empresas atuantes na produção de celulose e fabricação de papéis.

- Comércio: empresas atuantes no setor de varejo geral. 
- Telecomunicações: empresas atuantes no fornecimento e prestação de serviço de telecomunicação.

- Eletroeletrônicos: empresas atuantes na fabricação e fornecimento de bens de tecnologia, domésticos e empresariais.

- Têxtil: empresas atuantes na fabricação de bens têxteis, como vestuário e produtos domésticos.

- Veículos e Peças: empresas atuantes na fabricação e comercialização de veículos na indústria automotiva, ferroviária e aeroviária.

- Química: empresas atuantes na produção, no varejo e na distribuição de produtos químicos.

- Energia Elétrica: empresas atuantes na produção, no varejo e na distribuição de energia elétrica, independente da fonte.

- Mineração: empresas atuantes na mineração de recursos minerais e comercializado junto às siderurgias e metalurgias.

- Minerais não Metálicos: empresas atuantes na produção de bens não metálicos, como vidro e revestimento cerâmico.

- Agro e Pesca: empresas atuantes na exploração de terras agriculturáveis.

- Petróleo e Gás: empresas atuantes na produção de bens, no varejo e na distribuição de petróleo e gás.

- Fundos: empresas atuantes no setor de securitização e gestão de investimento.

- Máquinas Industriais: empresas atuantes na fabricação, importação e comercialização de bens para indústria.

- Software e Dados: empresas atuantes no setor de tecnologia, como prestação de serviço de dados. 


\section{RESULTADOS}

\subsection{Análise dos resultados do modelo global}

Segundo Wooldridge (2009), em uma perspectiva de análise, a parte mais complexa da logit é a apresentação e interpretação dos resultados. Duas formas de análise do modelo logit serão utilizadas: Tabela de classificação do modelo e Curva ROC. A tabela de classificação compara, através de um ponto de corte, a classificação prevista versus a observada. A sensibilidade e a especificidade do modelo demonstram, respectivamente, o percentual de acerto das ocorrências em casos de parecer limpo e o acerto das ocorrências em casos de parecer modificado. A curva ROC (Receiver Operating Characteristic) demonstra como seriam a sensibilidade e a especificidade se fossem calculadas para cada probabilidade entre 0 e 1. Assim, quanto maior a área abaixo da curva, maior a capacidade de o modelo discriminar os grupos (Fávero et al., 2009).

A curva de probabilidade do Audit Outcome é equivalente ao histograma dos dados da amostra, devido à probabilidade de o evento ocorrer (Equação 10). A área inferior à curva de probabilidade no caso de pareceres entre o ponto de corte e $0 \%$, por exemplo, equivale à especificidade. $\mathrm{O}$ ponto de corte ao qual a porcentagem de sensibilidade se equivale à porcentagem de especificidade é de aproximadamente $62,6 \%$.

\section{Figura 7 - Curva de probabilidade do parecer de auditoria}

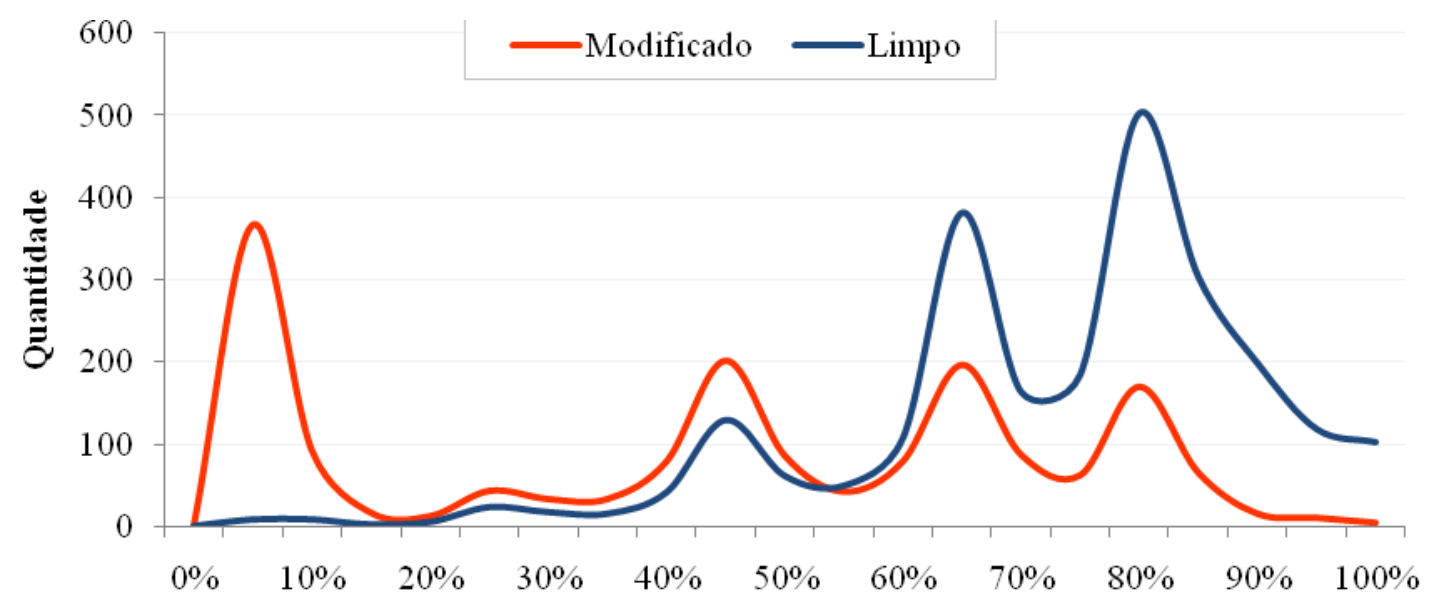

Prob(AuditOutcome) 
A Curva ROC do modelo de probabilidade de Audit Outcome possui área abaixo equivalente a 0,8 , indicando uma discriminação excelente entre os grupos (Fávero et al., 2009). O modelo global possui aproximadamente $43 \%$ de pareceres acima do ponto de corte sendo modificados, enquanto sua classificação seria como limpo. Entre os pareceres emitidos como limpos, 12,8\% são emitidos como limpos, enquanto o modelo os classifica como modificados.

Tabela 5 - Classificação do modelo

\begin{tabular}{|c|c|c|c|c|c|}
\hline \multicolumn{6}{|c|}{ MODELO } \\
\hline & & MODIFICADO & LIMPO & $\begin{array}{c}\text { Proporção } \\
(\%)\end{array}$ & \\
\hline \multirow{3}{*}{ AMOSTRA } & MODIFICADO & 964 & 731 & 56,9 & Especificidade \\
\hline & LIMPO & 309 & 2.107 & 87,2 & Sensibilidade \\
\hline & & & & 74,7 & Acerto do modelo \\
\hline
\end{tabular}

\subsection{Resultados do modelo de previsibilidade do parecer de auditoria}

Na Tabela 6 - Resultado da regressão logit, são apresentados os resultados da regressão logística robusta obtida através da análise das variáveis do arcabouço teórico ${ }^{17}$.

Tabela 6 - Resultado da regressão logit

\begin{tabular}{|c|c|c|c|c|c|}
\hline $\begin{array}{c}\text { Variável } \\
\text { Independente } \\
\end{array}$ & Coeficiente & $\begin{array}{c}\begin{array}{c}\text { Standard } \\
\text { error }\end{array} \\
\end{array}$ & $\mathbf{Z}$ & p-value & \\
\hline Const & $-2,7165$ & 0,275455 & $-9,8617$ & $<0,00001$ & $(* * *)$ \\
\hline SPOS & $-0,5862$ & 0,136262 & $-4,3017$ & 0,00002 & $(* * *)$ \\
\hline LNEG & $-0,2300$ & 0,218048 & $-1,0546$ & 0,29162 & \\
\hline Audit Delay & $-0,7632$ & 0,076767 & $-9,9412$ & $<0,00001$ & $(* * *)$ \\
\hline Msaudit_ativo & $-0,9955$ & 0,177841 & $-5,5976$ & $<0,00001$ & $(* * *)$ \\
\hline Mssector_receita & 0,3260 & 0,127547 & 2,5558 & 0,0106 & $(* *)$ \\
\hline ESPEC & 4,2080 & 0,611360 & 6,8830 & $<0,00001$ & $(* * *)$ \\
\hline BIGN & 0,1550 & 0,104925 & 1,4772 & 0,13962 & \\
\hline Leverage & $-0,0223$ & 0,011916 & $-1,8701$ & 0,06147 & $(*)$ \\
\hline PLdummy & 2,9846 & 0,270603 & 11,0296 & $<0,00001$ & $(* * *)$ \\
\hline LLdummy & 0,7717 & 0,089404 & 8,6320 & $<0,00001$ & $(* * *)$ \\
\hline Log-likelihood & $-2117,18$ & \multicolumn{2}{|c|}{$\mathrm{R}^{2}$ ajustado } & 0,236109 & \\
\hline
\end{tabular}

Tomando-se por base a Tabela 11, pode-se concluir que as variáveis de qualidade da auditoria possuem significância estatística, com exceção da variável BIGN (quatro maiores empresas

\footnotetext{
${ }^{17}$ Através do teste de variância dos fatores (VIF) não foram detectados indícios de multicolinearidade entre as variáveis independentes.
} 
de auditoria). Um motivo para a não significância estatística dessa variável seria sua forte correlação com as variáveis de market share, que demonstram a existência de quase-renda e de especialização em determinado setor ${ }^{18}$. Esse evento, no entanto, é uma oportunidade de pesquisa sobre a relação da reputação do auditor com o resultado do trabalho da auditoria.

O indicador de qualidade da contabilidade, que relaciona a oportunidade da companhia em gerenciar seus resultados buscando lucros, apresenta significância estatística em nível de 1\%, enquanto o reconhecimento tempestivo de perdas não tem significância estatística ${ }^{19}$.

Através da análise do arcabouço teórico (Tabela 1), pode-se comparar os sinais esperados pela teoria e pela revisão da literatura com os sinais das variáveis independentes do modelo. Dentre as variáveis detectadas, a única que apresenta diferença entre o sinal esperado e o observado é o reconhecimento de grandes perdas, cuja variável, no entanto, não é estatisticamente significante ao modelo. A diferença entre os sinais, portanto, é um indício de que os auditores não são sensíveis ao efeito positivo embasado pelo conservadorismo da companhia em casos de reconhecimento tempestivo de grandes perdas ${ }^{20}$. Essa relação, no entanto, deve ser mais explorada através do aumento da base de dados (possível ajuste na significância da variável) ou da confirmação de que a hipótese relacionada a esse sinal deve ser refutada. Conclui-se que o modelo global proposto possui acurácia satisfatória, e que, portanto, há indícios de associação entre a opinião do auditor contida no relatório de auditoria e as métricas de qualidade da contabilidade e de qualidade da auditoria.

\footnotetext{
${ }^{18}$ As correlações entre as variáveis MS auditasset e MS sector profit com BIGN são, respectivamente, 0,587 e 0,479 .

${ }^{19}$ Há forte correlação da variável LNEG com o lucro (LLdummy) e o patrimônio líquido positivo (PLdummy), sendo que com a retirada de ambas as variáveis a significância de LNEG é inferior a 1\%, e seu sinal mantém-se negativo. No entanto, a acurácia do modelo global se reduz a 71\%. As correlações entre as variáveis LLdummy e PLdummy com LNEG são, respectivamente, 0,449 e 0,632.

${ }^{20}$ Dechow et al. (2010) defendem que o reconhecimento de resultados se dá pela habilidade do sistema contábil para capturar a performance verdadeira de uma companhia, fator de qualidade que está fora da dimensão de controle do auditor.
} 
Tabela 7 - Sinais das variáveis independentes

\begin{tabular}{lcc}
\hline \multicolumn{1}{c}{ Variável independente } & Sinal esperado & Sinal observado \\
\hline Managing earning toward targets (SPOS) & - & - \\
Reconhecimento de grandes perdas (LNEG) & + & - \\
Audit Delay (AD) & - & - \\
Market share (audit) & - & + \\
Market share (sector) & + & + \\
Especialização (ESPEC) & + & + \\
BIG - N & + & - \\
Leverage & - & + \\
PLdummy & + & + \\
LLdummy & + & \\
\hline
\end{tabular}

\subsection{Análise dos resultados por setor}

Através do modelo proposto, as análises das individualidades dos setores mostram oportunidades de pesquisa sobre a previsibilidade do parecer de auditoria. Há diferentes estruturas de capital e proporções de receitas influenciando a qualidade da contabilidade, além de desafios relacionados à amostra estudada, como a grande quantidade de variações da opinião dos auditores entre os setores.

Buscando-se um auxílio para desdobramentos desta pesquisa, calculou-se a sensibilidade e a especificidade por setor, com base no modelo global. A análise permite concluir que setores como Energia Elétrica e Química possuem um grande desafio no construto teórico, devido ao baixo valor de sua especificidade. Esperando uma análise visual sobre os resultados, utilizaram-se a análise de cluster e a análise multidimensional para a exploração das fusões e junções dos setores. 
Figura 8 - Dendrograma de dois clusters

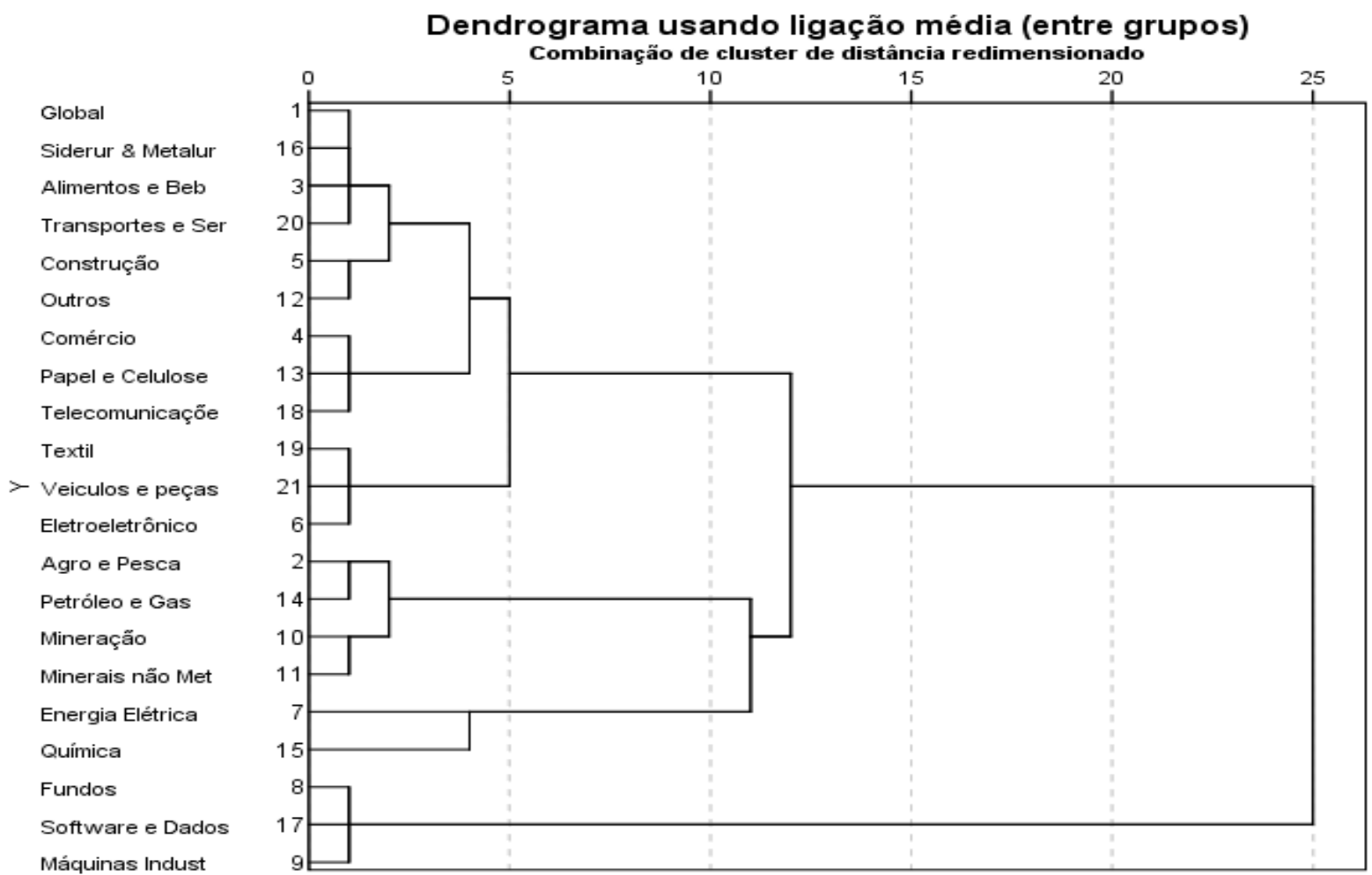

Figura 9 - Análise multidimensional dos setores

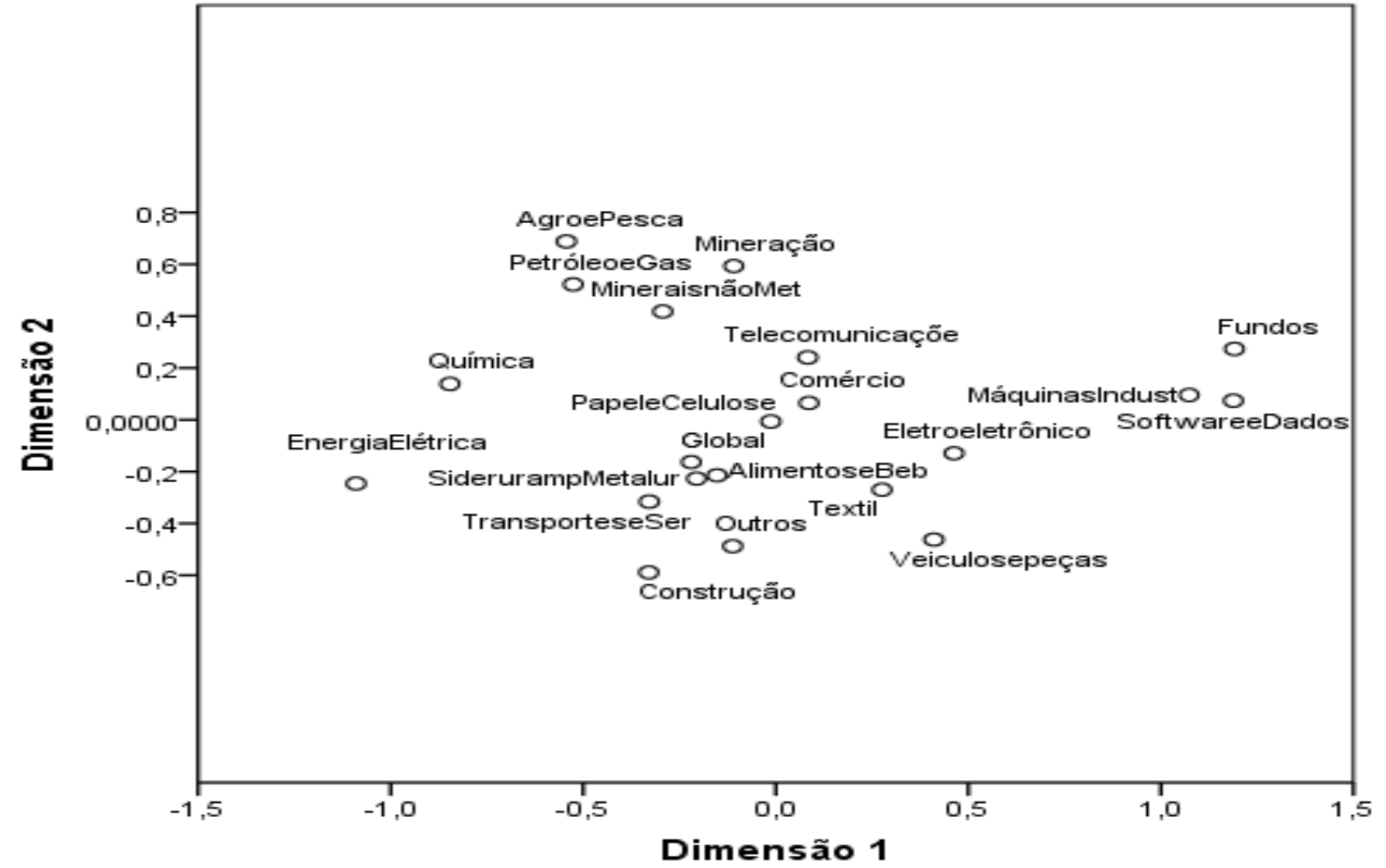


As análises exploratórias possibilitam detectar as fusões entre os setores e as possíveis variáveis a serem analisadas, demonstrando, a princípio, três clusters. Por exemplo, a junção entre os setores Energia Elétrica e Química à esquerda, na análise multidimensional, demonstra que existem relações entre ambos no modelo proposto, e que, portanto, as variáveis de controle podem ser exploradas para aproximar esses setores ao cluster com o "setor" Global.

Os setores Fundos, Software e Dados e Máquinas Industriais se juntam em um cluster separado. A fusão desses setores demonstra que os três possuem similaridades, como a alta porcentagem da especificidade, os pareceres limpos na amostra e o acerto global próximo de $100 \%$. 
Tabela 8 - Análise exploratória do modelo global por setor

\begin{tabular}{|c|c|c|c|c|c|c|}
\hline Setor & $\begin{array}{c}\text { Especificidade } \\
\text { (a) }(\%)\end{array}$ & $\begin{array}{c}\text { Sensibilidade } \\
(\mathrm{b})(\%) \\
\end{array}$ & $\begin{array}{l}\text { Acerto } \\
(\mathrm{c})(\%) \\
\end{array}$ & $\begin{array}{c}\text { \%Par. Limpo } \\
\text { (d) }\end{array}$ & Quantidade & Cluster \\
\hline Global & $56,87 \%$ & $87,21 \%$ & $74,70 \%$ & $58,77 \%$ & 4111 & 1 \\
\hline Alimentos e Bebidas & 58,8 & 81,4 & 72,9 & 62,2 & 225 & 1 \\
\hline $\begin{array}{l}\text { Transportes e } \\
\text { Serviços }\end{array}$ & 56,8 & 91,2 & 73,9 & 49,7 & 161 & 1 \\
\hline $\begin{array}{l}\text { Siderurgia e } \\
\text { Metalurgia }\end{array}$ & 59,3 & 86,6 & 75,0 & 57,4 & 364 & 1 \\
\hline Construção & 61,4 & 78,1 & 68,7 & 43,7 & 272 & 1 \\
\hline Outros & 66,8 & 78,7 & 73,0 & 52,3 & 771 & 1 \\
\hline Papel e Celulose & 61,3 & 93,2 & 82,2 & 65,6 & 90 & 1 \\
\hline Comércio & 63,2 & 91,2 & 83,4 & 72,2 & 205 & 1 \\
\hline Telecomunicações & 58,5 & 88,0 & 82,0 & 79,5 & 200 & 1 \\
\hline Eletroeletrônicos & 82,1 & 87,5 & 86,0 & 72,0 & 100 & 1 \\
\hline Têxtil & 77,4 & 89,2 & 84,7 & 61,8 & 359 & 1 \\
\hline Veículos e Peças & 85,7 & 86,4 & 86,1 & 58,3 & 252 & 1 \\
\hline Química & 27,2 & 89,1 & 65,3 & 61,5 & 239 & 2 \\
\hline Energia Elétrica & 29,2 & 89,2 & 54,2 & 41,5 & 515 & 2 \\
\hline Mineração & 42,9 & 93,5 & 86,8 & 86,8 & 53 & 2 \\
\hline Minerais não Metálicos & 41,2 & 98,0 & 83,8 & 75,0 & 68 & 2 \\
\hline Agro e Pesca & 25,0 & 97,1 & 83,7 & 81,4 & 43 & 2 \\
\hline Petróleo e Gás & 30,4 & 100,0 & 82,0 & 74,2 & 89 & 2 \\
\hline Fundos & 100,0 & 100,0 & 100,0 & 100,0 & 13 & 3 \\
\hline Máquinas Industriais & 100,0 & 96,6 & 97,0 & 90,8 & 65 & 3 \\
\hline Software e Dados & 100,0 & 96,3 & 96,3 & 100,0 & 27 & 3 \\
\hline \multicolumn{7}{|c|}{$\begin{array}{l}\text { (a) Especificidade: percentual de acerto das ocorrências em casos de pareceres modificados. } \\
\text { (b) Sensibilidade: percentual de acerto das ocorrências em casos de pareceres limpos. } \\
\text { (c) Acerto: equivale ao acerto do modelo, referente à classificação do modelo (Tabela 10). } \\
\text { (d) \%Par Limpo: equivale ao percentual de pareceres limpos na cross-section. }\end{array}$} \\
\hline
\end{tabular}




\subsection{Análises adicionais}

\subsubsection{Análise dos resultados temporais}

A distribuição da curva de probabilidade do relatório de auditoria foi segregada temporalmente. Portanto, esta seção analisa se a distribuição de probabilidades do parecer de auditoria possui diferenças no vetor tempo. A análise baseia-se na realização de cortes de períodos na amostra, a fim de se avaliar a correlação entre a curva de probabilidade total e a curva de probabilidade por ano. Os setores, nesse caso, foram unidos pela segregação de clusters apresentada na seção anterior.

A amostra de dados analisada está compreendida entre 1999 e 2012. Na análise temporal do modelo global, não há diferenças entre as curvas de probabilidade por ano e a curva de probabilidade do parecer com opinião tanto modificada quanto limpa. Em relação ao modelo global, tal qual apresentado na seção de análise dos clusters, este possui forte correlação com os clusters, independentemente da opinião, com exceção apenas do cluster 3, que possui uma curva de probabilidade com forte concentração à direita nos casos dos pareceres com opinião limpa.

Entre os pareceres com probabilidade de opinião limpa, tanto o cluster 1 como o cluster 2 possuem uma alta correlação com o modelo global atemporal. Entre os pareceres modificados, no entanto, o cenário é ligeiramente diferente. Os pareceres de ambos os clusters apresentam uma leve queda de correlação no período de 2012, sendo o principal motivo um aumento na probabilidade de os pareceres de auditoria serem limpos. Para o cluster 1, o aumento da probabilidade dos pareceres de auditoria em 2012 aconteceu com a redução dos pareceres com probabilidade inferior a $40 \%$ em aproximadamente $22 \%$, e o aumento dos pareceres entre $55 \%$ e $70 \%$ em $14 \%$. O principal motivo dentre esses casos foi o aumento das métricas de qualidade da auditoria, especificamente a diminuição das variáveis de quaserenda. 
Tabela 9 - Correlação temporal da curva de probabilidade do parecer de auditoria 1999/2012

\begin{tabular}{|c|c|c|c|c|c|c|c|c|c|}
\hline & & & urva de $P$ & b(A) Lim & & & va de Pro & (A) Modific & ado \\
\hline & Ano & $\begin{array}{c}\text { vS } \\
\text { Global } \\
(* * *) \\
\end{array}$ & $\begin{array}{c}\text { vs } \\
\text { Cluster } 1 \\
(* * *)\end{array}$ & $\begin{array}{c}\text { vs } \\
\text { Cluster } 2 \\
(* * *)\end{array}$ & $\begin{array}{c}\text { vs } \\
\text { Cluster } 3\end{array}$ & $\begin{array}{c}\text { vs } \\
\text { Global } \\
(* * *) \\
\end{array}$ & $\begin{array}{c}\text { vs } \\
\text { Cluster } 1 \\
(* * *) \\
\end{array}$ & $\begin{array}{c}\text { vs Cluster } \\
2\end{array}$ & $\begin{array}{c}\text { vs Cluster } \\
\mathbf{3}\end{array}$ \\
\hline & 1999 & ,931 & 895 & 877 & ,143 & ,901 & ,863 &, $594(* * *)$ &, $657(* * *)$ \\
\hline & 2000 & ,960 & ,937 & ,933 & ,387(*) & ,810 & ,782 &, $523(* *)$ &, $657(* * *)$ \\
\hline & 2001 & ,974 & ,966 & ,869 & ,387(*) & ,948 & ,921 &, $497(* *)$ & , 176 \\
\hline & 2002 & ,975 & ,971 & ,658 & ,395(*) & ,932 & ,900 &, $726(* * *)$ &, $657(* * *)$ \\
\hline & 2003 & ,927 & ,946 & ,803 & ,023 & ,941 & 874 &, $438(* *)$ & - \\
\hline ๘ี & 2004 & ,884 & 919 & ,750 & ,276 & 896 & 835 &, $430(*)$ & - \\
\hline$\frac{0}{0}$ & 2005 & 891 & ,869 & 897 &,- 035 & 919 & 839 & ,439(**) & - \\
\hline & 2006 & ,966 & ,956 & ,923 & ,346 & ,944 & ,861 &, $444(* *)$ & - \\
\hline & 2007 & ,980 & ,979 & ,827 & ,293 & ,898 & ,805 &, $376(*)$ & - \\
\hline & 2008 & ,906 & 891 & ,688 &, 271 & ,956 & 906 & ,378(*) & - \\
\hline & 2009 & ,968 & ,943 & ,818 &, $438(* *)$ & ,946 & ,918 &, $449(* *)$ & - \\
\hline & 2010 & ,818 & ,838 & ,690 & ,183 & ,773 & ,733 &, $612(* * *)$ & - \\
\hline & 2011 & 891 & ,822 & ,824 & ,390(*) & ,850 & ,875 &, $605(* * *)$ & - \\
\hline & 2012 & ,912 & ,848 & ,806 & ,262 &, 621 & ,629 &, 363 & - \\
\hline & Total & 1,000 & 991 & ,956 & ,368 & 1,000 & ,950 &, $594(* * *)$ &, $685(* * *)$ \\
\hline
\end{tabular}

Nota: A correlação equivale ao cluster/amostra pela série temporal com a curva de probabilidade da amostra global, demonstrada graficamente no histograma apresentado na Figura 7, considerando a opinião do auditor independente para a cross-section.

$(*)$ valores significativos $(\mathbf{p}<, 1) ;(* *)$ valores muito significativos $(\mathbf{p}<, 05) ;(* * *)$ valores altamente significativos $(\mathbf{p}$ $<, 01)$.

A análise temporal permite concluir que, no vetor tempo, o modelo proposto possui assertividade. Esta informação permite corroborar com a hipótese de que há associação entre a opinião do auditor contida no relatório de auditoria e as métricas de qualidade da contabilidade a opinião do auditor independente, fruto de predisposições ex ante do auditor. Eventos temporais como crise econômica e adoção de uma nova legislação ou prática contábil, ocorridos dentro do universo analisado, não tiveram influência, assim sendo, a análise metodológica encontra fundamentos. 


\subsubsection{Análise descritiva por cluster}

\subsubsection{Cluster 1}

O cluster 1 é composto pelos setores na parte superior do dendrograma, sendo: Alimentos e Bebidas, Transportes e Serviços, Siderurgia e Metalurgia, Construção, Outros, Papel e Celulose, Comércio, Telecomunicações, Eletroeletrônicos, Têxtil e Veículos e Peças. Esse cluster se caracteriza pela forte relação com o modelo global, tendo assim a distribuição do resultado de auditoria alinhada ao modelo proposto.

\section{Figura 10 - Curva de probabilidade do parecer de auditoria - Cluster 1}

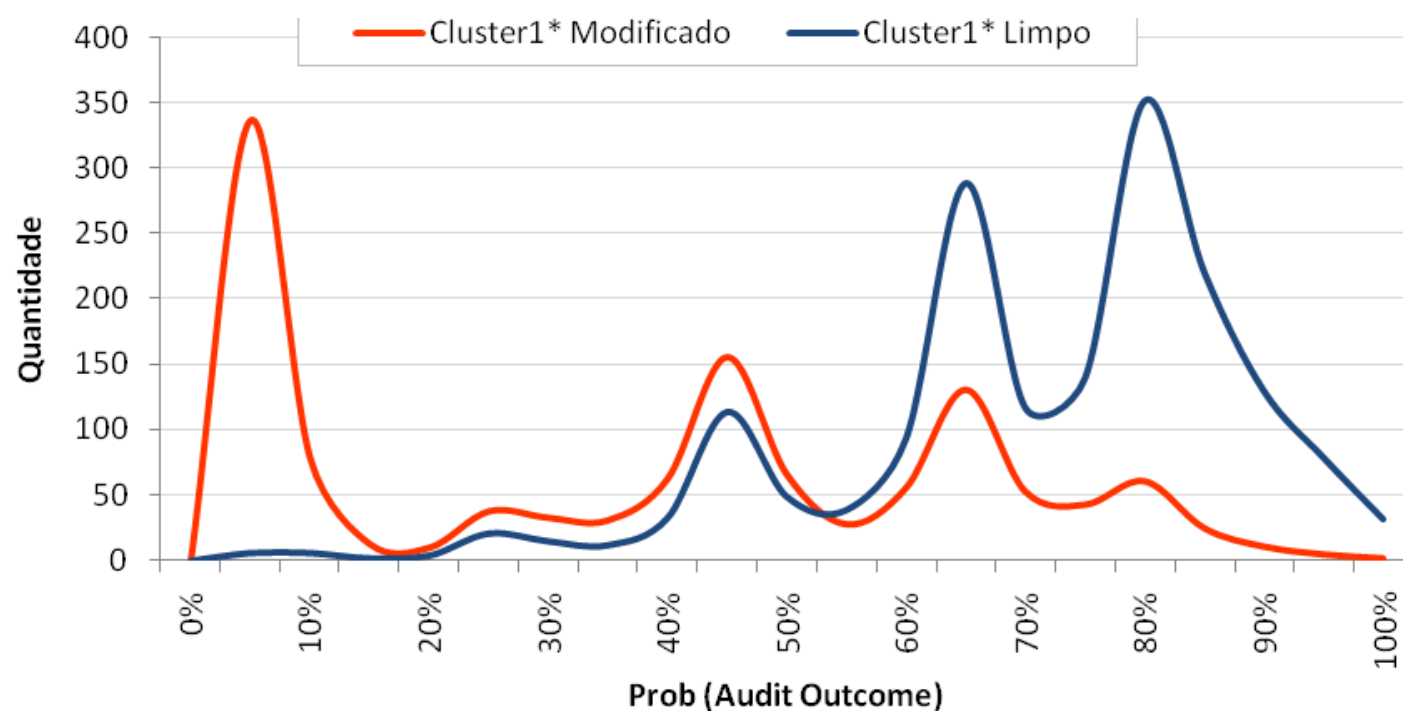

O histograma da Figura 9 demonstra a probabilidade segundo a regressão logística (Equação 10) para os setores compostos pelo cluster global. Assim, percebe-se que a área inferior à distribuição dos pareceres modificados, antes do ponto de corte de 0,5, equivale a 66,6\%. Enquanto isso, a área inferior à curva de probabilidade do resultado de auditoria, para os casos em que o parecer foi limpo, equivale a $85,1 \%$. O índice de acerto total do modelo para esse cluster corresponde a 77,4\%, superior, portanto, à amostra total. 
Tabela 10 - Análise descritiva - Cluster 1

\begin{tabular}{|c|c|c|c|c|c|c|c|c|c|c|c|c|}
\hline \multirow{2}{*}{$\begin{array}{c}\text { Variável } \\
\text { Parecer } \\
\text { auditoria }\end{array}$} & \multicolumn{2}{|c|}{$\begin{array}{c}\text { Proporção } \\
(\%)\end{array}$} & \multicolumn{2}{|c|}{ SPOS } & \multicolumn{2}{|c|}{ LNEG } & \multicolumn{2}{|c|}{ AD } & \multicolumn{2}{|c|}{$\begin{array}{l}\text { \% Msaudit } \\
\text { ativo }\end{array}$} & \multicolumn{2}{|c|}{$\begin{array}{l}\text { \% Mssector } \\
\text { receita }\end{array}$} \\
\hline & $\begin{array}{c}\text { Modific } \\
\text { ado }\end{array}$ & $\begin{array}{c}\text { Lim } \\
\text { po }\end{array}$ & $\begin{array}{c}\text { Modific } \\
\text { ado }\end{array}$ & $\begin{array}{c}\text { Lim } \\
\text { po }\end{array}$ & $\begin{array}{c}\text { Modific } \\
\text { ado }\end{array}$ & $\begin{array}{c}\text { Lim } \\
\text { po }\end{array}$ & $\begin{array}{c}\text { Modific } \\
\text { ado }\end{array}$ & $\begin{array}{c}\text { Lim } \\
\text { po }\end{array}$ & $\begin{array}{c}\text { Modific } \\
\text { ado }\end{array}$ & $\begin{array}{c}\text { Lim } \\
\text { po }\end{array}$ & $\begin{array}{c}\text { Modific } \\
\text { ado }\end{array}$ & $\begin{array}{c}\text { Lim } \\
\text { po }\end{array}$ \\
\hline Total & 41,4 & 58,6 & 98 & 110 & 287 & 39 & 937 & 750 & 27,9 & 9,9 & 53,6 & 42,7 \\
\hline $\mathrm{P} \& \mathrm{C}$ & 34,4 & 65,6 & 5 & 4 & 1 & 0 & 23 & 12 & 39,5 & 10 & 57,8 & 72,6 \\
\hline Com & 27,8 & 72,2 & 1 & 9 & 14 & 0 & 33 & 46 & 31,7 & 10,7 & 55,8 & 53,8 \\
\hline Cons & 56,3 & 43,8 & 19 & 9 & 6 & 2 & 147 & 76 & 38,3 & 16,3 & 61,9 & 41,1 \\
\hline Eletro & 28 & 72 & 1 & 5 & 7 & 2 & 25 & 24 & 67,4 & 5 & 86,2 & 73,4 \\
\hline $\mathrm{A} \& \mathrm{~B}$ & 37,8 & 62,2 & 5 & 13 & 19 & 4 & 62 & 61 & 32,3 & 11,8 & 66 & 59,5 \\
\hline Outros & 47,7 & 52,3 & 32 & 18 & 70 & 13 & 304 & 225 & 27,3 & 12,9 & 41,7 & 28,9 \\
\hline $\mathrm{T} \& \mathrm{~S}$ & 50,3 & 49,7 & 4 & 3 & 17 & 4 & 51 & 35 & 18,7 & 1,9 & 55,2 & 38,4 \\
\hline S\&M & 42,6 & 57,4 & 13 & 14 & 44 & 0 & 89 & 71 & 14,4 & 13,5 & 48,6 & 43,8 \\
\hline Tele & 20,5 & 79,5 & 9 & 10 & 9 & 4 & 26 & 53 & 7,3 & 4,8 & 43,6 & 30,9 \\
\hline Têxtil & 38,2 & 61,8 & 6 & 21 & 41 & 5 & 94 & 94 & 29,6 & 6,7 & 60,5 & 33,3 \\
\hline $\mathrm{V} \& \mathrm{P}$ & 41,7 & 58,3 & 3 & 4 & 59 & 5 & 83 & 53 & 28,3 & 5,7 & 63,1 & 54,9 \\
\hline Variável & \multicolumn{2}{|c|}{ \% ESPEC } & \multicolumn{2}{|c|}{ BIGN } & \multicolumn{2}{|c|}{ LEVERAGE } & \multicolumn{2}{|c|}{$\mathbf{P L}$} & \multicolumn{2}{|l|}{$\mathbf{L L}$} & \multicolumn{2}{|c|}{$\%$ Prob (Out) } \\
\hline $\begin{array}{l}\text { Parecer } \\
\text { auditoria }\end{array}$ & $\begin{array}{c}\text { Modific } \\
\text { ado }\end{array}$ & $\begin{array}{c}\text { Lim } \\
\text { po }\end{array}$ & $\begin{array}{c}\text { Modific } \\
\text { ado }\end{array}$ & $\begin{array}{c}\text { Lim } \\
\text { po }\end{array}$ & $\begin{array}{c}\text { Modific } \\
\text { ado }\end{array}$ & $\begin{array}{c}\text { Lim } \\
\text { po }\end{array}$ & $\begin{array}{c}\text { Modific } \\
\text { ado }\end{array}$ & $\begin{array}{c}\text { Lim } \\
\text { po }\end{array}$ & $\begin{array}{c}\text { Modific } \\
\text { ado }\end{array}$ & $\begin{array}{c}\text { Lim } \\
\text { po }\end{array}$ & $\begin{array}{c}\text { Modific } \\
\text { ado }\end{array}$ & $\begin{array}{c}\text { Lim } \\
\text { po }\end{array}$ \\
\hline Total & 2,3 & 6,9 & 508 & 1270 & 2,2 & 1,3 & 819 & 1743 & 513 & 1407 & 35,9 & 68,8 \\
\hline $\mathrm{P} \& \mathrm{C}$ & 7,7 & 19,5 & 13 & 50 & 1,6 & 1 & 29 & 59 & 16 & 50 & 49,4 & 82,2 \\
\hline Com & 0,8 & 9 & 18 & 115 & 5,3 & 1,4 & 37 & 148 & 23 & 125 & 35,6 & 73,5 \\
\hline Cons & 3,7 & 6,5 & 63 & 62 & 0,7 & 0,7 & 130 & 119 & 93 & 101 & 43,4 & 64,9 \\
\hline Eletro & 2,5 & 18,3 & 6 & 57 & 0 & 1,6 & 19 & 72 & 13 & 46 & 32,3 & 76,3 \\
\hline$A \& B$ & 3,4 & 7,5 & 19 & 79 & 2,5 & 1,5 & 60 & 139 & 34 & 107 & 39 & 67,7 \\
\hline Outros & 1,1 & 2,4 & 165 & 280 & 1,3 & 0,8 & 273 & 400 & 166 & 324 & 37,6 & 63 \\
\hline $\mathrm{T} \& \mathrm{~S}$ & 5,4 & 11 & 54 & 78 & 1,5 & 1,9 & 53 & 76 & 33 & 64 & 41,5 & 71,7 \\
\hline S\&M & 1,6 & 5,5 & 69 & 141 & 0,7 & 1 & 85 & 209 & 71 & 181 & 36,5 & 69,9 \\
\hline Tele & 3,9 & 7,6 & 32 & 142 & 7 & 1,6 & 33 & 158 & 18 & 115 & 44,5 & 71,1 \\
\hline Têxtil & 1,4 & 5,3 & 35 & 155 & 7,3 & 2 & 76 & 222 & 29 & 169 & 27,7 & 67,7 \\
\hline $\mathrm{V} \& \mathrm{P}$ & 2 & 8,1 & 34 & 111 & 0,8 & 2 & 24 & 141 & 17 & 125 & 16,1 & 71,4 \\
\hline $\begin{array}{l}\text { Abreviatı } \\
\text { (Cons), O } \\
\text { (Eletro) e }\end{array}$ & $\mathrm{F}$ & Des & $(A B)$ & Ialls & 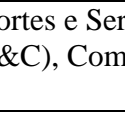 & & 2 & gla & Taiu & $\& N$ & onstru & \\
\hline
\end{tabular}

A análise descritiva auxilia no exame das curvas de probabilidade de Audit Outcome. As companhias com parecer modificado e com área de probabilidade inferior a $20 \%$ têm como principal característica grandes prejuízos, gerando baixos valores de qualidade da contabilidade e de variáveis de controle (Endividamento, Passivo a Descoberto e Prejuízo). Há, também, indicativos de baixa qualidade da auditoria nesse grupo de empresas: mediana de 81 dias de atraso no parecer de auditoria; enquanto no cluster a mediana é de 67 dias de atraso; e apenas $27 \%$ das empresas desse grupo possuem uma grande firma como auditor. 


\subsubsection{Cluster 2}

O segundo cluster é composto pelos setores na parte intermediária do dendrograma, sendo: Agro e Pesca, Química, Energia Elétrica, Mineração, Minerais não Metalúrgicos e Petróleo e Gás. Esse cluster se caracteriza pela baixa especificidade do modelo e da sua alta sensibilidade, portanto, baixo acerto para os pareceres com opinião modificada e alto acerto nos pareceres limpos.

Nesse cluster, vale ressaltar a baixa quantidade de pareceres limpos na média (com especial ressalva para o setor Energia Elétrica). Dentre os motivos levantados para as modificações de opinião nos pareceres desse cluster, encontram-se medidas legislativas que não se enquadram no aparato contábil, gerando em alguns momentos ênfase e/ou ressalva ao parecer de uma companhia $^{21}$. O modelo proposto não possui assertividade a essas medidas setoriais, por se enquadrarem na opção contábil da companhia. Esse assunto é também abordado na seção “Análise dos resultados e a qualidade da auditoria", especificamente no tópico de empresas com parecer modificado e com alta qualidade da auditoria.

Figura 11 - Curva de probabilidade do parecer de auditoria - Cluster 2

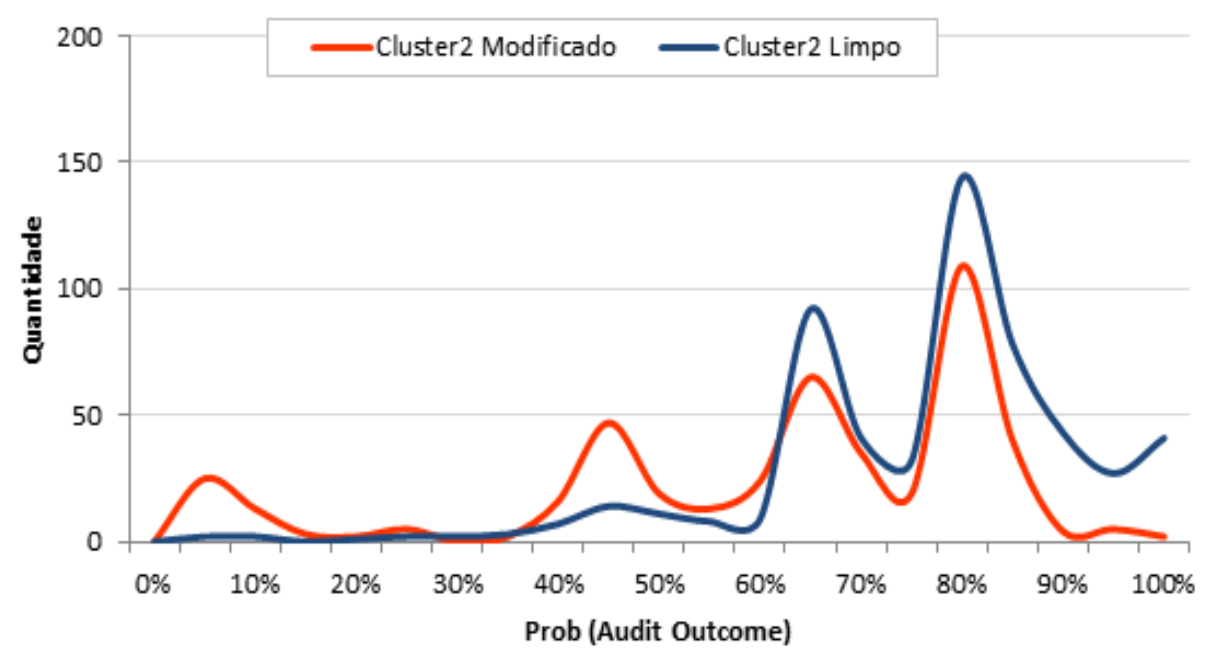

${ }^{21}$ Deliberação CVM 183, de 1995: não execução de reavaliação periódica de ativos. 


\subsubsection{Análise dos resultados e a qualidade da auditoria}

Atrelado ao objetivo desta pesquisa de analisar a associação entre a opinião do auditor contida no relatório de auditoria e as métricas de qualidade da contabilidade e de qualidade da auditoria, um possível desdobramento teórico é a relação entre a qualidade da auditoria e a opinião do auditor independente. Assim sendo, esta seção procura destrinchar as métricas de qualidade da auditoria utilizadas e a opinião do auditor independente, associando em quadrantes a probabilidade de o relatório de auditoria não possuir modificação de opinião (Equação 10) e a qualidade da auditoria.

Figura 12 - Quadrantes Audit Quality

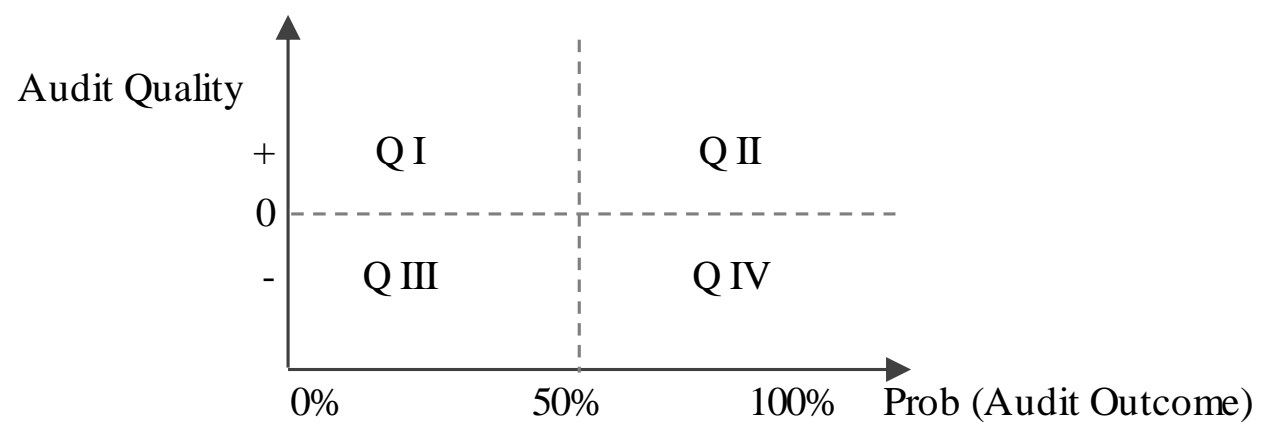

É esperado que os pareceres sem modificação de opinião pelo auditor se localizem nos quadrantes II e IV, enquanto os pareceres com modificação de opinião devem se encontrar nos quadrantes I e III. Como explicitado na seção “Análise dos resultados”, existem opiniões na curva de probabilidade do resultado de auditoria que estão fora desses padrões esperados. As porcentagens esperadas, no entanto, equivalem a 74,7\% do total de pareceres analisados (porcentagem de acerto do modelo), sendo 87,2\% de acertos dentro dos pareceres com opinião limpa do auditor, e 56,9\% de acertos dentro dos pareceres com opinião modificada do auditor. 
Tabela 11 - Probabilidade (\%) do Audit Outcome e a qualidade da auditoria

\begin{tabular}{|c|c|c|c|c|c|c|c|c|}
\hline \multirow[b]{2}{*}{ Quadrante/Opinião } & \multicolumn{2}{|c|}{ Global } & \multicolumn{2}{|c|}{ Cluster 1} & \multicolumn{2}{|c|}{ Cluster 2} & \multicolumn{2}{|c|}{ Cluster 3} \\
\hline & Parecer & $\begin{array}{c}\% \text { Vert } \\
(*)\end{array}$ & Parecer & $\begin{array}{c}\% \text { Vert } \\
(*)\end{array}$ & Parecer & $\begin{array}{c}\% \text { Vert } \\
(*)\end{array}$ & Parecer & $\begin{array}{c}\% \text { Vert } \\
(*)\end{array}$ \\
\hline Q I Limpo & 0,4 & 0,7 & 0,5 & 0,8 & 0,2 & 0,4 & 0,0 & 0,0 \\
\hline Q II Limpo & 36,9 & 62,9 & 34,4 & 58,8 & 40,1 & 72,3 & 78,1 & 82,8 \\
\hline Q III Limpo & 7,1 & 12,1 & 8,3 & 14,1 & 4,2 & 7,5 & 2,9 & 3,0 \\
\hline Q IV Limpo & 14,3 & 24,3 & 15,4 & 26,3 & 11,0 & 19,9 & 13,3 & 14,1 \\
\hline Esperado Limpo(a) & 51,3 & 87,2 & 49,9 & 85,1 & 51,1 & 92,1 & 91,4 & 97,0 \\
\hline Q I Modificado & 1,8 & 4,5 & 2,1 & 5,2 & 1,2 & 2,7 & 0,0 & 0,0 \\
\hline Q II Modificado & 10,2 & 24,8 & 6,7 & 16,3 & 21,6 & 48,7 & 0,0 & 0,0 \\
\hline Q III Modificado & 21,6 & 52,4 & 25,4 & 61,4 & 11,9 & 26,8 & 5,7 & 100,0 \\
\hline Q IV Modificado & 7,6 & 18,3 & 7,1 & 17,2 & 9,7 & 21,9 & 0,0 & 0,0 \\
\hline $\begin{array}{l}\text { Esperado } \\
\text { Modificado(b) }\end{array}$ & 23,4 & 56,9 & 27,5 & 66,6 & 13,1 & 29,5 & 5,7 & 100,0 \\
\hline Esperado Total(c) & 74,7 & & 77,4 & & 64,3 & & 97,1 & \\
\hline \multicolumn{9}{|c|}{$\begin{array}{l}\text { (a) O valor esperado limpo refere-se ao acerto do modelo, nos casos de pareceres com opinião limpa, dentre os quadrantes II e } \\
\text { IV. } \\
\text { (b) O valor esperado modificado refere-se ao acerto do modelo, nos casos de pareceres com opinião modificada, dentre os } \\
\text { quadrantes I e III. } \\
\text { (c) O valor esperado total se refere ao acerto do modelo, equivalente à Tabela } 8 \text { - Análise exploratória do modelo global } \\
\text { por setor. } \\
\text { (*) \% Vert se refere à porcentagem de pareceres no quadrante, dentre o total de pareceres com a mesma opinião. }\end{array}$} \\
\hline
\end{tabular}

As análises adicionais objetivaram identificar as discrepâncias dos valores encontrados, e, assim, buscar melhorias para o modelo preditivo do parecer de auditoria. Em consonância com Sunder (1997), foram identificados três pontos para elucidação dos valores discrepantes: (I) fatores de qualidade da auditoria ex post, influenciando a escolha do auditor ${ }^{22}$; (II) fatores de qualidade no processo de auditoria ${ }^{23}$; e (III) medidas regulatórias e que influenciam a opinião do auditor e as escolhas contábeis ${ }^{24}$.

As curvas de pareceres dos modelos se equivalem ${ }^{25}$, havendo comportamentos e proporções equivalentes, independentemente da opinião emitida pelo auditor. Na representação gráfica da Figura 12, é possível detectar as semelhanças entre as curvas e as relações exemplificadas a seguir. Os pareceres limpos no primeiro e no segundo quadrante correspondem a 7,5\% do total de pareceres, sendo que a maior parte dos casos encontra-se com a probabilidade de

\footnotetext{
${ }^{22}$ Incerteza associada, principalmente, a contingências não resolvidas - efeito quase-renda.

${ }^{23}$ Problemas no escopo do trabalho da auditoria.

${ }^{24}$ Inconsistência nos métodos contábeis.

${ }^{25}$ Correlação estatisticamente significante a $1 \%$, equivalente a $76,6 \%$.
} 
parecer de auditoria próxima do ponto de corte (mediana de 41,4\%). Enquanto isso, os pareceres com modificação de opinião, nos quadrantes II e III, possuem mediana de 67,8\% (próxima do ponto de equilíbrio do modelo proposto de $62,6 \%$ ).

Figura 13 - Curva de probabilidade do parecer e a qualidade da auditoria - opinião limpa

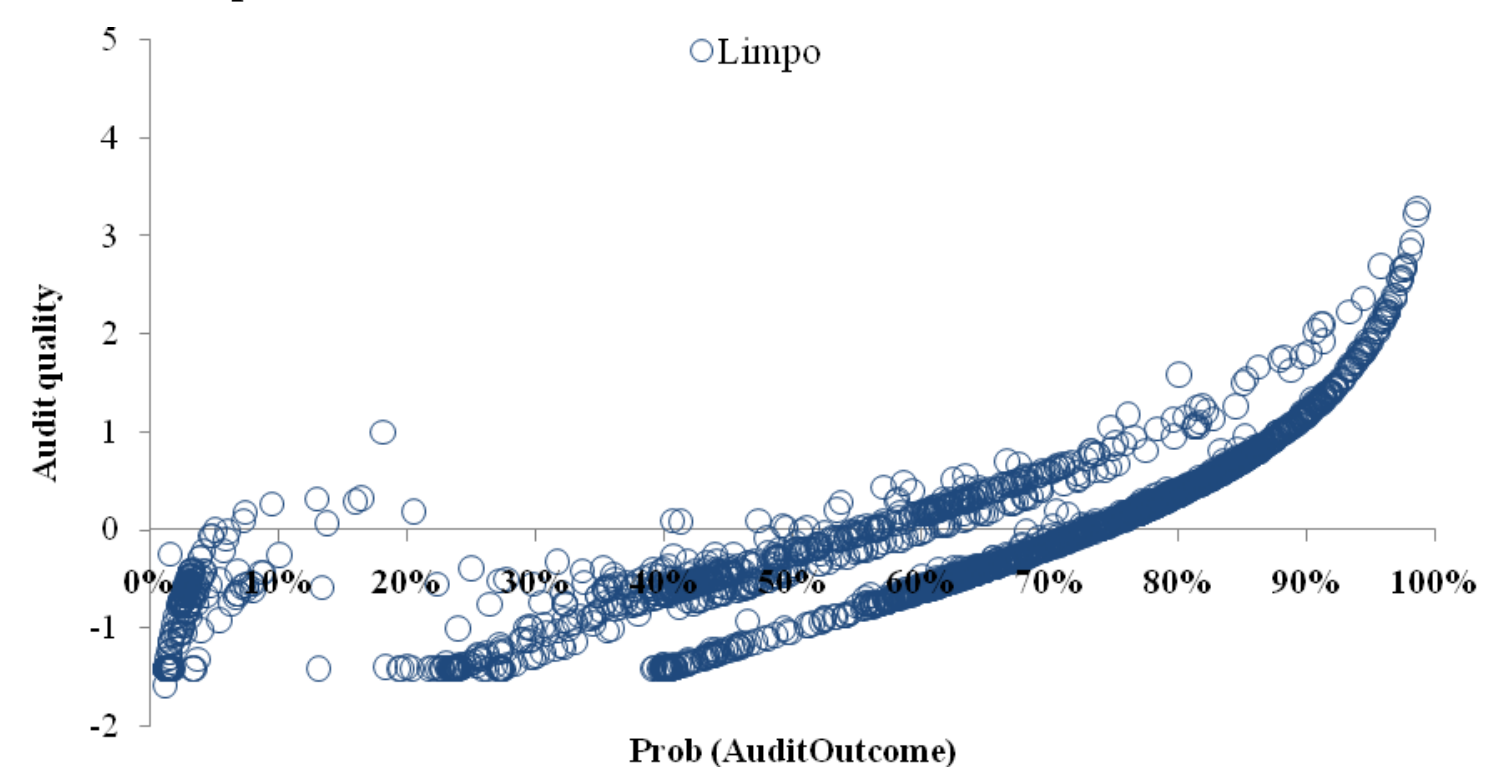

Figura 14 - Curva de probabilidade do parecer e a qualidade da auditoria - opinião modificada

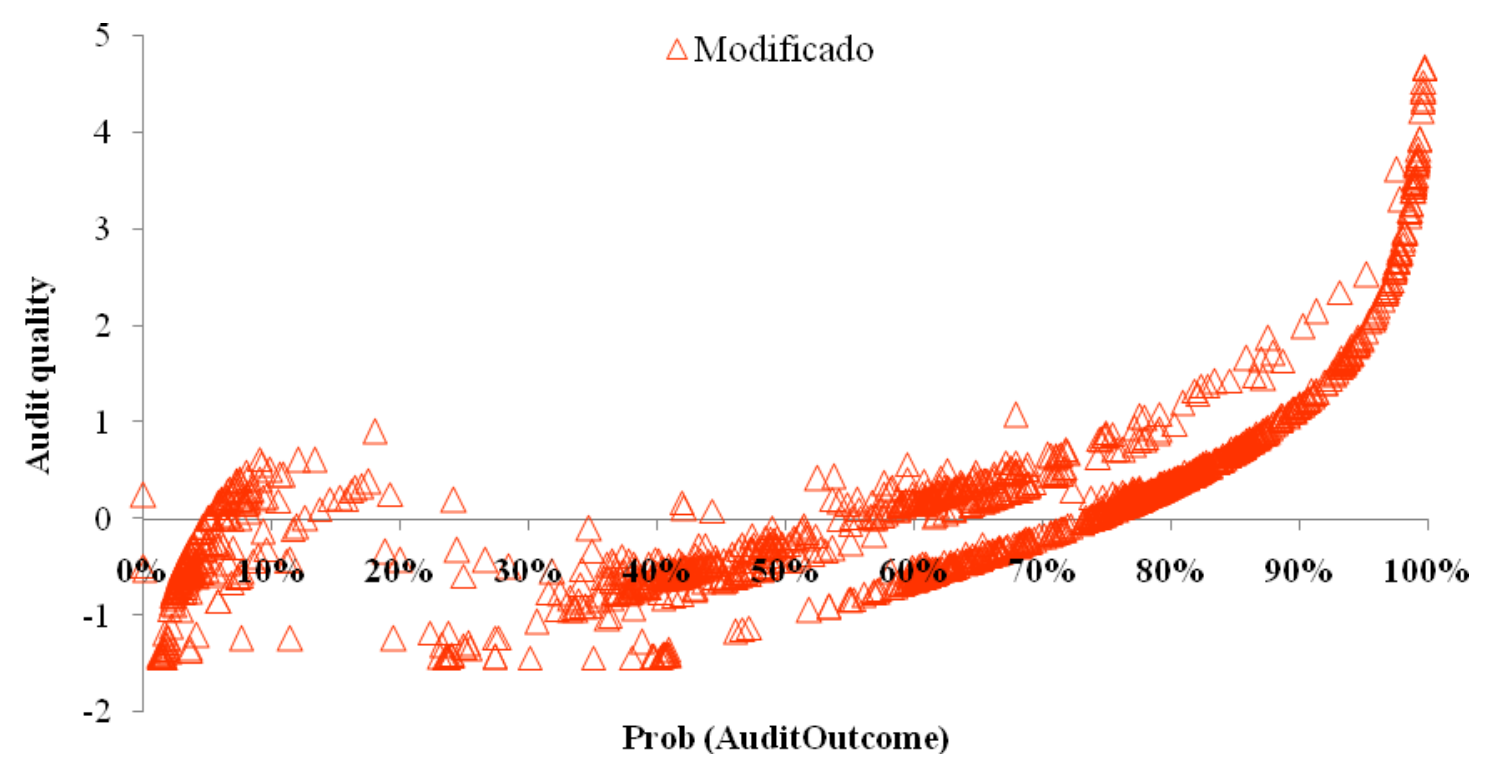


Parecer com opinião limpa e com "alta qualidade" de auditoria, sendo que o modelo associa a probabilidade de o parecer obter modificação de opinião (Quadrante I)

Esse grupo contém 16 empresas dos clusters 1 e 2. Como fator comum a esse quadrante, notou-se que houve alteração de auditor nesse período, ou no período seguinte, e o parecer do ano seguinte conteve modificação de opinião. Esse evento é indicativo de baixa qualidade da auditoria, como demonstrado por Braunbeck (2010) no IQUA. Assim sendo, há nesse caso uma baixa qualidade da auditoria ex post, reflexo da quase-renda auditoria e cliente, não capturada nas variáveis do modelo proposto.

Parecer com opinião limpa e com baixa qualidade da auditoria, sendo que o modelo associa a probabilidade de o parecer obter modificação de opinião (Quadrante III)

Dentre as companhias desse grupo, notou-se que os pareceres tiveram uma alta demora para a emissão. Enquanto na amostra total estudada a mediana para a emissão do parecer de auditoria foi de 63 dias, nos casos desse grupo a demora teve mediana equivalente a 78 dias. Portanto, há indícios de que no processo de auditoria houve a detecção de problemas pelo auditor, e que as "negociações" auditor x cliente alteraram a disposição do auditor para gerar uma opinião modificada.

Parecer com opinião modificada e com alta qualidade da auditoria, sendo que o modelo associa a probabilidade de o parecer não obter modificação de opinião (Quadrante II)

Dentre as companhias com essa anomalia, os pareceres possuem opinião modificada por questões regulatórias setoriais. Nesse quadrante, destacam-se as empresas do cluster 2. Assim sendo, as justificativas para tal anomalia são exemplificadas na seção “Análise descritiva por cluster - cluster 2". Portanto, os motivos para a modificação de opinião do auditor dependem de características não abordadas no modelo de previsibilidade desta pesquisa.

Parecer com opinião modificada e com baixa qualidade da auditoria, sendo que o modelo associa a probabilidade de o parecer não obter modificação de opinião (Quadrante IV)

Tal qual ocorreu no quadrante III dos pareceres sem modificação de opinião pelo auditor, notou-se que os pareceres desse grupo tiveram alta demora na emissão do parecer (mediana 
equivalente a 79 dias). Nesses casos, no entanto, a relação entre auditor e cliente não foi suficiente para que o parecer não tivesse modificação de opinião.

\section{Figura 15 - Qualidade da auditoria e a opinião do auditor}

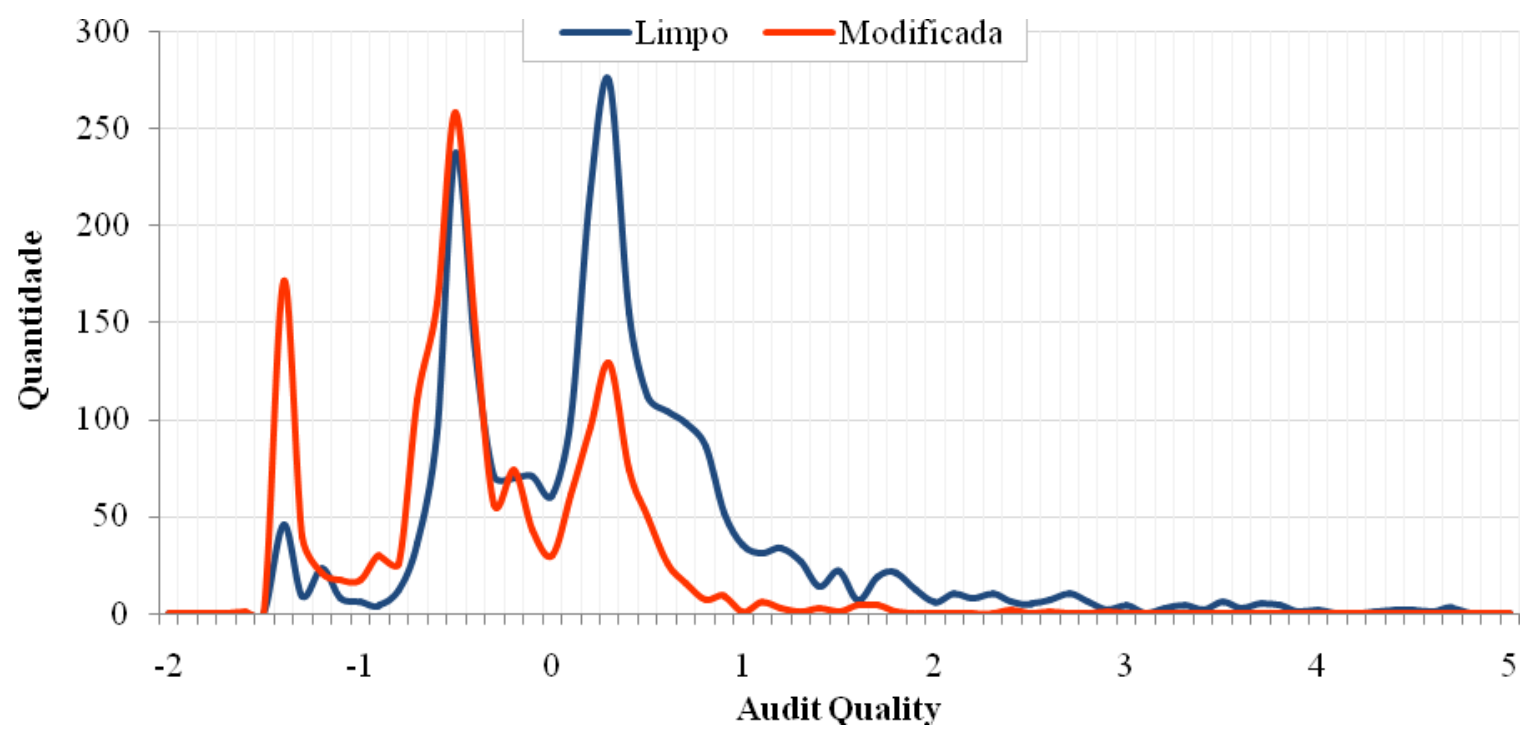

A representação gráfica da Figura 14 demonstra que os pareceres com opinião modificada estão majoritariamente abaixo do limite da qualidade da auditoria, equivalente a zero no modelo proposto. Enquanto isso, nos casos dos pareceres com opinião limpa, existe uma forte aproximação ao ponto de corte de qualidade da auditoria equivalente a zero. Essa aproximação é demonstrada pelo quadrante III da Figura 13, com peso superior ao da variável de atraso no parecer de auditoria (AD). 


\title{
5 CONSIDERAÇÕES
}

\begin{abstract}
"O que vale para a auditoria é a credibilidade. Não que elas não forcem os limites em busca de rentabilidade, mas há um momento em que isso passa a ser arriscado demais."
\end{abstract}

(Ribeiro, 2014)

\subsection{Resumo dos resultados encontrados}

O presente estudo teve por objetivo analisar um modelo de estimação da opinião do auditor independente à luz das teorias de qualidade da auditoria e de qualidade da contabilidade. Esse objetivo previa a resposta à seguinte questão de pesquisa:

Qual a associação da opinião contida no relatório de auditoria com as métricas de qualidade da auditoria e de qualidade da contabilidade?

O modelo de estimação, objetivo geral da pesquisa, foi identificado com base na plataforma teórica. Os resultados do modelo indicam que há associação da opinião do auditor com a qualidade da contabilidade e a qualidade da auditoria, nas empresas de capital aberto do Brasil. Esta afirmação é possível ao analisar a curva ROC do modelo, com curva abaixo equivalente à 0,8 e discriminação considerada excelente na literatura.

Corroborando a essa afirmativa, identificou-se, em análise adicional, que a curva de probabilidade da opinião do auditor possui distribuição atemporal, não havendo, assim, divergências entre os anos da amostra estudada. Para esta afirmativa foram testadas as curvas de probabilidade do parecer de auditoria por cluster, e em modelo global, para os pareceres com opinião com, ou sem, modificação de opinião. A correlação das curvas por ano ao modelo global proposto é significante para os pareceres sem modificação no modelo global, cluster 1 e cluster 2, e a correlação das curvas com modificação de opinião ao modelo global proposto é significante aos grupos global e cluster 1 .

Dentre os fatores detectados no referencial de pesquisa, alguns, não foram significantes ao modelo proposto. O reconhecimento de grandes perdas, parte da teoria da qualidade de 
contabilidade, que busca a detecção do conservadorismo da contabilidade não foi estatisticamente significante fruto da baixa percepção deste fator pelo auditor. $\mathrm{O}$ arcabouço teórico de qualidade de auditoria dita que uma firma de auditoria com alta reputação de mercado e com portfolio vasto, será mais robusta que suas concorrentes. Este fator, que é expresso como o tamanho da firma de auditoria, não teve significância na opinião do auditor independente, sendo o principal motivo a força das outras variáveis (quase-renda e variáveis de controle) ao modelo proposto.

Destes fatores de qualidade de contabilidade e de qualidade de auditoria, em outra análise do estudo, detectou-se a influência de tais indicadores na opinião do auditor independente. Aos fatores estatisticamente significantes, a influência sobre a opinião do auditor independente possui comportamento como delineado no constructo das variáveis independentes desta pesquisa. A variável de reconhecimento de grandes perdas, mesmo não tendo significância estatística ao modelo, foi analisada por seu sinal esperado ser diferente ao da expectativa no referencial da pesquisa. Este resultado corrobora a não percepção do auditor do conservadorismo contábil, dito como fator de qualidade da contabilidade nas normas internacionais.

Buscando-se uma exploração mais clara do objetivo geral, o primeiro objetivo específico foi delineado com o intuito de detectar particularidades na amostra estudada. Detectou-se que o modelo proposto distingue os setores da amostra em três clusters. Esses grupos se diferenciam pela especificidade e pela sensibilidade do modelo. Em especial, detectou-se que o primeiro cluster possui sensibilidade (acerto em casos de opinião modificada) e especificidade (acertos em caso de opinião limpa) próxima do modelo global, ambas superiores a 50\% dos casos. $\mathrm{O}$ segundo cluster, no entanto, possui sensibilidade superior ao primeiro cluster, mas especificidade inferior. Nesses casos, identificou-se que os setores contidos nesse cluster possuem companhias altamente suscetíveis a medidas regulatórias setoriais, um dos motivos a suscitar modificação de opinião dos auditores independentes pela contabilização divergente dos padrões contábeis geralmente aceitos (Sunder, 1997). O último cluster possui poucas empresas, e é relacionado a setores de alta tecnologia, nos quais o modelo teve acerto próximo de $100 \%$.

Como segundo objetivo específico, esta pesquisa comprometeu-se a identificar desvios entre a qualidade da auditoria, a opinião do auditor e a probabilidade de o parecer possuir uma 
opinião específica (segundo o modelo proposto). Os resultados dessa seção permitiram identificar com mais nitidez as discrepâncias identificadas na análise setorial, e atribuir mais acurácia ao modelo. Segregando a análise em quadrantes, os principais motivos de discrepância são: qualidade da auditoria ex post influenciando a opinião do auditor; problemas no processo de auditoria da companhia, tal qual o atraso na emissão do parecer; e medidas regulatórias setoriais que influenciam a escolha contábil divergente da prática contábil geralmente aceita.

A sensibilidade do modelo, e a especificidade, foram exploradas e apresentadas na Tabela 11 com as qualidades de auditoria. Abaixo se encontram o resumo dos resultados do modelo:

Tabela 12 - Resumo dos resultados encontrados

\begin{tabular}{|c|c|c|c|c|c|c|c|c|}
\hline \multirow[b]{2}{*}{ Quadrante/Opinião } & \multicolumn{2}{|c|}{ Global } & \multicolumn{2}{|c|}{ Cluster 1} & \multicolumn{2}{|c|}{ Cluster 2} & \multicolumn{2}{|c|}{ Cluster 3} \\
\hline & Parecer & $\begin{array}{c}\% \text { Vert } \\
(*)\end{array}$ & Parecer & $\begin{array}{c}\% \text { Vert } \\
(*)\end{array}$ & Parecer & $\begin{array}{c}\% \text { Vert } \\
(*)\end{array}$ & Parecer & $\begin{array}{c}\% \text { Vert } \\
(*)\end{array}$ \\
\hline Esperado Limpo( $\left.{ }^{a}\right)$ & 51,3 & 87,2 & 49,9 & 85,1 & 51,1 & 92,1 & 91,4 & 97,0 \\
\hline $\begin{array}{l}\text { Esperado } \\
\text { Modificado(b) }\end{array}$ & 23,4 & 56,9 & 27,5 & 66,6 & 13,1 & 29,5 & 5,7 & 100,0 \\
\hline Esperado Total( $\left({ }^{c}\right)$ & 74,7 & & 77,4 & & 64,3 & & 97,1 & \\
\hline $\begin{array}{l}\text { (a) O valor esperado limpc } \\
\text { IV (sensibilidade). } \\
\text { (b) O valor esperado mod } \\
\text { quadrantes I e III (especif } \\
\text { (c) O valor esperado total } \\
\text { por setor. } \\
\text { (*) } \% \text { Vert se refere à por }\end{array}$ & $\begin{array}{l}\text { fere-se ao a } \\
\text { cado refere- } \\
\text { dade). } \\
\text { refere ao ac } \\
\text { ntagem de p }\end{array}$ & $\begin{array}{l}\text { erto do mo } \\
\text { e ao acert } \\
\text { rto do mod } \\
\text { receres no }\end{array}$ & $\begin{array}{l}\text { delo, nos cas } \\
\text { do modelo, } \\
\text { lo, equivale } \\
\text { uadrante, d }\end{array}$ & $\begin{array}{l}\text { ss de pare } \\
\text { nos casos } \\
\text { te à Tabe } \\
\text { ntre o tota }\end{array}$ & $\begin{array}{l}\text { res com opin } \\
\text { e pareceres } \\
8 \text { - Anális } \\
\text { de pareceres }\end{array}$ & $\begin{array}{l}\text { ão limpa, } \\
\text { om opini } \\
\text { explora } \\
\text { om a mes }\end{array}$ & $\begin{array}{l}\text { modre os qua } \\
\text { modificadi } \\
\text { ria do mod } \\
\text { a opinião. }\end{array}$ & $\begin{array}{l}\text { rantes II e } \\
\text { dentre os } \\
\text { lo global }\end{array}$ \\
\hline
\end{tabular}

\subsection{Considerações sobre a pesquisa}

Assim, consistentemente à teoria de quase-renda explorada no referencial de pesquisa, pode se concluir que existem limitantes à atuação do auditor independente como um redutor dos custos de agência em uma entidade ("sistema"). Sua inserção, a fim de mitigar o relacionamento entre administrador e gestor, possui predisposições que afetam o resultado de seu trabalho divulgado nas demonstrações financeiras - sua opinião. Em casos de companhias abertas com alta participação de outros agentes interessados (como acionistas minoritários, consumidores, fornecedores) há de se ponderar a opinião emitida pela firma de auditoria. Vale destacar que este estudo não pesquisou e aferiu se há, ou não, independência da firma de auditoria na relação auditor - auditado, sendo objeto de outros estudos dentre a teoria de auditoria. 
A opinião do auditor independente, de acordo com os resultados do modelo proposto, é influenciada pela qualidade da auditoria ex ante. No entanto, fatores endógenos da capacidade da companhia influenciam a opinião do auditor, mais que os fatores identificados no arcabouço teórico. Dentre estes fatores identificados nesta pesquisa, e pouco explorados em outros estudos de auditoria, está o fato de o auditado possuir, ou não, passivo a descoberto.

Tabela 13 - Resumo dos impactos dos fatores na opinião do auditor

\begin{tabular}{|c|c|c|c|c|c|c|}
\hline & & & & Limpo & Modificado & \\
\hline Variável independente & Natureza & Descrição resumida & $\begin{array}{l}\text { Sinal } \\
\text { observado }\end{array}$ & & Influência & $\%$ \\
\hline Constante & & & - & & $89,1 \%$ & \multirow{6}{*}{$\mid 100 \%$} \\
\hline $\begin{array}{l}\text { Managing earning } \\
\text { toward targets (SPOS) }\end{array}$ & binária & $0<\mathrm{ROA}<0,01$ & - & & $0,9 \%$ & \\
\hline $\begin{array}{l}\text { Reconhecimento de } \\
\text { grandes perdas (LNEG) }\end{array}$ & binária & $\mathrm{ROA}<0,2$ & - & & $0,1 \%$ & \\
\hline Audit Delay (AD) & binária & $\begin{array}{l}\text { Atraso médio no } \\
\text { parecer }\end{array}$ & - & & $7,6 \%$ & \\
\hline Market share (audit) & $\%$ & $\begin{array}{l}\text { Ativo no portfolio da } \\
\text { auditoria }\end{array}$ & - & & $1,5 \%$ & \\
\hline Leverage & escalar & Endividamento & - & & $0,8 \%$ & \\
\hline Market share (sector) & $\%$ & $\begin{array}{l}\text { Receita no setor do } \\
\text { portfolio da auditoria }\end{array}$ & + & $26,8 \%$ & & \multirow{5}{*}{$\mid 100 \%$} \\
\hline Especialização (ESPEC) & $\%$ & Receita no setor & + & $6,1 \%$ & & \\
\hline BIG $-\mathbf{N}$ & binária & Big Four & + & $7,5 \%$ & & \\
\hline PLdummy & binária & $\begin{array}{l}\text { Patrimônio Líquido } \\
\text { Positivo }\end{array}$ & + & $52,6 \%$ & & \\
\hline LLdummy & binária & Lucro no exercício & + & $6,9 \%$ & & \\
\hline
\end{tabular}

Dentre o arcabouço teórico desta pesquisa, a especialização do auditor dentre seu portfolio, variável próxima ao conceito de quase-renda, demonstrou-se relevante. Assim, nota-se que o conhecimento do auditor no setor e sua dependência à companhia auditada, afetam a opinião do auditor independente.

As limitações desta pesquisa se relacionam à forma de escolha da amostra e às métricas de qualidade da contabilidade utilizadas. A amostragem por conveniência permite ao pesquisador apenas deduzir o resultado da amostra utilizada. Enquanto isso, no caso das teorias de qualidade da contabilidade, notou-se uma forte relação das métricas utilizadas com o conceito de conservadorismo. Estas métricas pouco influenciaram na opinião modificada do auditor independente, diferente do esperado no arcabouço teórico. A principal variável de qualidade de auditoria que influencia o parecer modificado, o atraso na emissão do parecer de auditoria, não possui significância estatística, limitando conclusões sobre este grupo. 
O fato de termos alto peso da constante na regressão incita que existem fatores não identificados no arcabouço teórico. No cenário brasileiro há limitação nos dados de auditoria. Variáveis como honorários de auditoria e possíveis litígios ensejam quase-renda do auditorauditado, e não estão disponíveis. Há de se destacar que parte do resíduo do modelo encontrase em fatores do arcabouço teórico de impactos à qualidade de auditoria ex post, como mudanças de auditor e reapresentação das demonstrações financeiras.

Conclui-se que a abordagem desta pesquisa permite corroborar a hipótese de associação entre a opinião do auditor contida no relatório de auditoria tanto com as métricas de qualidade da auditoria, quanto com as métricas de qualidade da contabilidade. Tais evidências colocam desafios à governança corporativa das companhias. A opinião do auditor independente deve ser vista, pelos usuários das informações financeiras, como fonte essencial à tomada de decisão de negócios. Possíveis conflitos devem ser abordados pelos órgãos reguladores e mitigados.

Estes órgãos devem reduzir os custos de oportunidade do auditor. Medidas que tragam maior segurança diminuíram possíveis litígios, e terão impactos positivos à independência da opinião do auditor. Regras de compliance nacional, aumento da penalização a atos fraudulentos, ou estruturação mandatória de comitês de governança interna, são destaques à redução do risco do auditor.

Neste âmbito, vale ressaltar, a adoção brasileira do rodízio de auditoria. Convívios prolongados entre auditor e auditado, podem deteriorar a independência do auditor (Braunbeck, 2008). Esta pesquisa contribui ao arcabouço teórico neste âmbito. Aferindo que as firmas de auditoria possuem predisposições ao aceite de um determinado cliente e que sua dependência financeira ao auditado influencia sua opinião.

Contudo, deve-se destacar que a metodologia proposta não enseja em estimar a opinião futura de um auditor independente em qualquer cenário. Por questões de amostra pesquisada, é possível imaginar outros ambientes regulatórios em que a predisposição do auditor possa ter outros fatores. No entanto, o mercado brasileiro foi utilizado por suscitar local propício a pesquisa. 


\subsection{Oportunidades para pesquisas futuras}

Este estudo pretendeu dar início a um debate sobre fatores que impactam a opinião do auditor, contida no relatório de auditoria. Portanto, destacam-se a seguir possíveis pesquisas a serem realizadas:

- além das variáveis deste estudo, outras variáveis de controle poderiam ser estudadas a fim de diminuir a especificidade do modelo. Detectam-se promissoras as variáveis de governança corporativa;

- detecção de outras abordagens de qualidade da contabilidade ex ante;

- aumento da série temporal e das cross-section, com vistas à utilização de outras técnicas estatísticas;

- detecção do comportamento da opinião do auditor independente em momentos de crise; e

- ampliação do escopo da amostra aos outros mercados emergentes e/ou a mercados já consolidados. 


\section{REFERÊNCIAS}

Akerlof, G. A. (1970). The market for "lemons": quality uncertainty and the market mechanism. The Quarterly Journal of Economics, 84(3), 448-500.

Arruñada, B. (1997). La calidad de la auditoria: incentivos privados y regulación. Madrid: Marcial Pons.

Ashton, R. H., Willingham, J. J., \& Elliot, R. K. (1987). An empirical analysis of audit delay. Journal of Accounting Research, 25(2), 275-292.

Balsam, S., Krishnan, J., \& Yang, J. S. (2003). Auditor industry specialization and earnings quality. Auditing: A Journal of Practice \& Theory, 22(2), 71-97.

Barth, M. E., Landsman, W. R.., \& Lang, M. H. (2008). International accounting standards and accounting quality. Journal of Accounting Research, 46(3).

Basu, S. (1997, December). The conservatism principle and the asymmetric timeliness of earnings. Journal of Accounting \& Economics, 24(1), 3-35.

Bradshaw, M., Richardson, S., \& Sloan, R. (2001). Do analysts and auditors use information in accruals? Journal of Accounting Research 39, 45-74. 
Braunbeck, G. O. (2010). Determinantes da qualidade das auditorias independentes no Brasil. Tese de doutorado, Universidade de São Paulo, São Paulo, SP, Brasil.

, \& Carvalho, L. N. (2008). Rodízio obrigatório de auditorias: emenda pior que o soneto? Congresso USP de Controladoria e Contabilidade, 8, 2008.

Butler, M., Leone, A., \& Willenborg, M. (2004). An empirical analysis of auditor reporting and its association with abnormal accruals. Journal of Accounting and Economics, 37, 139-165.

Carson, E. (2009). Industry specialization by global audit firm networks. Accounting Review, 84(2), 355-382.

Casterella, J. R., Francis, J. R., Lewis, B. L., \& Walker, P. L. (2004). Auditor industry specialization, client bargaining power, and audit pricing. Auditing, 23(1), 123-140.

Chen, C., Su, X., \& Zhao, R. (2000, Fall). An emerging market's reaction to initial modified audit opinions: evidence from the Shanghai stock exchange. Contemporary Accounting Research, 17(3), 429-455. 
Chen, H., Quingliang, T., Jiang, Y., \& Lin, Z. (2010). The role of international financial reporting standards in accounting quality: evidence from the European Union. Journal of International Financial Management and Accounting, 21(3).

Cushing, B. E. (1989). Discussion of the association between audit technology and audit delay. Auditing, 8(2), 38 .

DeAngelo, L. E. (1981a). Auditor independence, 'low balling', and disclosure regulation. Journal of Accounting and Economics, 3,113-127.

DeAngelo, L. E. (1981b) Auditor size and audit quality. Journal of Accounting and Economics, 3, 183-199.

Dechow, P. M., Ge, W., \& Schrand, C. (2010). Understanding earnings quality: a review of theproxies, their determinants and their consequences. Journal of Accounting and Economics, 50, 344-401.

Fávero, L. P., Belfiore, P., Silva, F. L., \& Chan, B. L. (2009). Análise de dados: modelagem multivariada para tomada de decisões (5a reimpr.). Rio de Janeiro: Elsevier.

Fung, S. Y. K., Gul, F. A., \& Krishnan, J. (2012). City-level auditor industry specialization, economies of scale, and audit pricing. Accounting Review, 87(4), 1281-1307. 
Geiger, M. A., \& RAMA, D. V. (2006, March). Audit firm size and going-concern reporting accuracy. Accounting Horizons, 20(1), 1-17.

Healy, P. M., \& Wahlen, J. M. (1999, December). A review of the earnings management literature and its implications for standard setting. Accounting Horizons, 13(4).

Herbohn, K., \& Ragunathan, V. (2008). Auditor reporting and earnings management: some additional evidence. Accounting \& Finance, 48(4), 575-601.

Hribar, P., Kravet, T. D., \& Wilson, R. J. (2010, April). A new measure of accounting quality. Available at $\quad$ SSRN: $\quad$ http://ssrn.com/abstract $=1283946 \quad$ or http://dx.doi.org/10.2139/ssrn.1283946

Huang, H., Liu, L., Raghunandan, K., \& Rama, D. V. (2007). Auditor industry specialization, client bargaining power, and audit fees: further evidence. Auditing, 26(1), 147-158.

Jaggi, B., \& Tsui, J. (1999). Determinants of audit report lag: further evidence from Hong Kong. Accounting \& Business Research, 30(1), 17-28.

Jensen, M., \& Meckling, W. (1976, October). Theory of the firm: managerial behavior, agency costs and ownership structure. Journal of Finance Economics, 3, 305-360.

Joe, J. R. (2003). Why press coverage of a client influences the audit opinion. Journal of Accounting Research, 41(1). 
Keefe, T. B., King, R. D., \& Gaver, K. M. (1994) Audit fees, industry specialization, and compliance with GAAS reporting standards. Auditing, 13(2), 41-55.

Kinney, W. R., \& McDaniel, L. S. (1993). Audit delay for firms correcting quarterly earnings. Auditing, 12(2), 135-142.

Knechel, W. R., Naiker, V., \& Pacheco, G. (2007). Does auditor industry specialization matter? Evidence from market reaction to auditor switches. Auditing, 26(1), 19-45.

Libby, R., Bloomfield, R., \& Nelson, M. W. (2002). Experimental research in financial accounting. Accounting, Organizations and Society, 27.

Lopes, A. B., \& Iudícibus, S. (2012). Teoria avançada da contabilidade (2a ed.). São Paulo: Atlas.

Martins, G. A., \& Theóphilo, C. R. (2009). Metodologia da investigação científica para ciências sociais aplicadas (2a ed.). São Paulo: Atlas.

Masli, A., Peters, G. F., Richardson, V. J., \& Sanchez, J. M. (2010). Examining the potential benefits of internal control monitoring technology. Accounting Review, 85(3), 10011034. 
Mong, S., \& Roebuck, P. (2005). Effect of audit report disclosure on auditor litigation risk. Accounting \& Finance, 45, 145-169.

Neal, T. L., \& Riley, Jr., R. (2004). Auditor industry specialist research design. Auditing, 23(2), 171-179.

Newton, J. D., \& Ashton, R. H. (1989). The association between audit technology and audit delay. Auditing, 8(2), 22.

Ribeiro, N. (2014). Petrobras empurra o auditor ao limite. Valor Econômico, Seção Empresas, Governo, Petrobras.

Simunic, D. A., \& Stein, M. T. (1987). Audit risk in a client portfolio context. Contemporary Accounting Research, 6(2), 329-343.

Sunder, S. (1997). Theory of accounting and control. Ohio: South-Western Cengage Learning.

Taylor, M. H. (2000). The effects of industry specialization on auditors' inherent risk assessments and confidence judgements. Contemporary Accounting Research, 17(4), 693-712. 
Watts, R. L., \& Zimmerman, J. L. (1983, October). Agency problems, auditing and the theory of the firm: some evidence. Journal of Law \& Economics, 26, 613-634.

(1986). Positive accounting theory. Englewood Cliffs: Prentice Hall.

Wooldridge, J. M. (2009). Introductory econometrics: a modern approach (4a ed.). Mason, $\mathrm{OH}$ : South-Western Cengage Learning. 